NBER WORKING PAPER SERIES

\title{
DOES VOCATIONAL EDUCATION WORK? EVIDENCE FROM A RANDOMIZED EXPERIMENT IN MONGOLIA
}

\author{
Erica M. Field \\ Leigh L. Linden \\ Ofer Malamud \\ Daniel Rubenson \\ Shing-Yi Wang \\ Working Paper 26092 \\ http://www.nber.org/papers/w26092
}

\author{
NATIONAL BUREAU OF ECONOMIC RESEARCH \\ 1050 Massachusetts Avenue \\ Cambridge, MA 02138 \\ July 2019
}

We would like to thank Matthew Bombyk, Jihae Hong, Jamie Johnston, Ken Lee, Ricardo Morel and Richard Sawyer from Innovation for Poverty Action; Richard Gaeta, Rebecca Goldsmith, Jack Molyneaux, Ryan Moore, Sophia Sahaf, Marc Shapiro, Cindy Sobieski, Jennifer Sturdy from the Millennium Challenge Corporation; and Boloroo N and Uuganbayar B. from the Millennium Challenge Account - Mongolia for all their help over the course of the project. Marius Karabaczek provided invaluable research assistance. The data collection and IPA's evaluation design support were funded by the Millennium Challenge Corporation for MCC's Vocational Education Project Evaluation. It was also supported by grant P2CHD042849 Population Research Center, awarded to the Population Research Center at The University of Texas at Austin by the Eunice Kennedy Shriver National Institute of Child Health and Human Development. The content is solely the responsibility of the authors and does not necessarily represent the official views of the National Institutes of Health or the Millennium Challenge Corporation. The views expressed herein are those of the authors and do not necessarily reflect the views of the National Bureau of Economic Research.

NBER working papers are circulated for discussion and comment purposes. They have not been peer-reviewed or been subject to the review by the NBER Board of Directors that accompanies official NBER publications.

(C) 2019 by Erica M. Field, Leigh L. Linden, Ofer Malamud, Daniel Rubenson, and Shing-Yi Wang. All rights reserved. Short sections of text, not to exceed two paragraphs, may be quoted without explicit permission provided that full credit, including $\odot$ notice, is given to the source. 
Does Vocational Education Work? Evidence from a Randomized Experiment in Mongolia Erica M. Field, Leigh L. Linden, Ofer Malamud, Daniel Rubenson, and Shing-Yi Wang NBER Working Paper No. 26092

July 2019

JEL No. I25,I26,J24

\section{ABSTRACT}

This paper estimates the impact of admission to formal vocational secondary programs on labor market outcomes in Mongolia. We conducted public lotteries to allocate scarce slots for approximately 8,000 students who applied to oversubscribed trades in 10 vocational schools during 2010, 2011, and 2012. We find that admission to oversubscribed vocational schools in Mongolia led to significantly higher employment, and increased earnings for women. These positive impacts appear to be due to the acquisition of more skills in specific trades, greater work intensity, and increased employment opportunities in high-paying sectors.

Erica M. Field

Department of Economics

Duke University

Social Sciences Building

Box 90097

Durham, NC 27708

and CEPR

and also NBER

emf23@duke.edu

Leigh L. Linden

Department of Economics

The University of Texas at Austin

2225 Speedway

BRB 1.116, C3100

Austin, Texas 78712

and NBER

leigh.linden@austin.utexas.edu

Ofer Malamud

School of Education and Social Policy

Northwestern University

Annenberg Hall

2120 Campus Drive

Evanston, IL 60208

and NBER

ofer.malamud@northwestern.edu
Daniel Rubenson

Department of Politics

Ryerson University

Jorgenson Hall 729

350 Victoria Street

Toronto, ON M5B 2K3

Canada

rubenson@ryerson.ca

Shing-Yi Wang

The Wharton School

University of Pennsylvania

3620 Locust Walk

Philadelphia, PA 19104

and NBER

was@wharton.upenn.edu 


\section{Introduction}

With enrollment in primary education having become nearly universal in many middleincome and developing countries, there is increased attention on secondary education. ${ }^{1}$ In addition to the prevailing issues of access and quality, ${ }^{2}$ an important question concerns the role of vocational training in secondary education: Can vocational training improve labor market outcomes for youth in developing countries? This is not a new question. A large literature comparing the returns to general and vocational education in developing countries emerged during the 1970s and continued through the 1990s, with extensive reviews by Zymelman (1976), Tilak (1988), and Psacharapolous (1987, 1993). Their conclusions were summarized in a 1995 World Bank Education Sector Review which stated that "comparative evaluations of...general and secondary education curricula indicated clearly that the rate of return was much higher to investments in general than in vocational secondary education" (IBRD, 1995, p.8). Yet many of the studies underlying these conclusions failed to address the possibility of selection bias when comparing general and vocational education (Bennel, 1996).

More recent papers estimating the impact of general and vocational education have attempted to address selection by exploiting exogenous variation in exposure to different types of education. For example, Malamud and Pop-Eleches (2010) examine a 1973 educational reform in Romania that shifted secondary-school students from vocational training to general education, finding similar rates of labor market participation and earnings between men in cohorts who received general education and those with vocational training. There have also been several randomized evaluations of vocational education and training programs in middle-income and

\footnotetext{
${ }^{1}$ Much progress has made since the adoption of the Millennium Development Goal 2 calling for universal primary education by 2015 (https://www.mdgmonitor.org/mdg-2-achieve-universal-primary-education/).

${ }^{2}$ For example, Duflo, Dupas and Kremer (2017) examine the impact of free secondary education in Ghana.
} 
developing countries. As we will elaborate shortly, most of these evaluations focus on relatively short programs of 3 to 6 months for low-skilled or unemployed youth, including Card et al. (2007) for the Dominican Republic, Attanasio et al. $(2011,2015)$ for Colombia, and Hirshleifer et al. (2014) for Turkey. With the notable exception of Hicks et al. (2017) for Kenya, none directly examine the impact of untargeted, long-term, formal vocational education programs.

This paper estimates the impact of admission to formal vocational secondary programs on labor market outcomes in Mongolia. ${ }^{3}$ To this end, we conducted randomized public lotteries in which applicants to 10 oversubscribed vocational schools were randomly assigned admissions both by school and specific trade of study in 2010, 2011, and 2012. The majority of the students applied to 2 or 2.5 year vocational programs after completing 9 years of schooling while others applied to shorter 1 year programs after completing the full 11 years of schooling. We then followed those students who were admitted and those who were rejected through 2015, collecting information on their educational attainment, employment, and earnings, as well as knowledge of their trades, work intensity, and other ancillary outcomes.

We find that admission to vocational schools in Mongolia led to significantly higher employment. For example, a year after completing school, those admitted to a vocational school were 4 percent more likely to be employed in a paid job and 9 percent more likely to have held a paid job lasting longer than one month. These impacts are substantially larger for women and increase over time (for up to three years after completing school). Admission to oversubscribed vocational schools also led to significantly increased earnings for women. For example, a year after completing school, women who were admitted to a 2-year vocational program earned 13

\footnotetext{
${ }^{3}$ This paper builds on the analysis described in Appendix E of the final evaluation report of MCC's Vocational Education and Training (VET) project prepared by the authors in Innovations for Poverty Action (2018): https://data.mcc.gov/evaluations/index.php/catalog/82.
} 
percent per month more in their most recent job and on average as compared to those who were not admitted. These improved labor market outcomes appear to be due to the acquisition of more skills in specific trades, greater work intensity, and increased employment opportunities in highpaying sectors. Moreover, they are mostly driven by students in early cohorts and disappear for the latest cohort which entered the labor market during an economic downturn.

These findings are in line with some of the previous literature on vocational education and training. Attanasio et al. $(2011,2015)$ evaluate the Jovenes en Accion program, which provided three months of in-classroom training and three months of on-the-job training to low-income unemployed youth in Colombia. Following up on these youth 13 to 15 months after they would have completed their training, they find that women randomly offered training earn almost 20 percent more in wages and have a 7 percent higher probability of paid employment than those not offered training. None of these outcomes are significant for men. The impacts remain significant in administrative data up to 10 years later. Card et al. (2007) evaluate the Juventud y Empleo initiative in the Dominican Republic which provides low-income youth with vocational training by private institutions up to a maximum of 350 hours. They find no impacts on employment outcomes but some evidence of a positive (10\%) effect on earnings per month among those who are working. Hirshleifer et al. (2014) evaluate the impact of vocational programs for the unemployed provided through the Turkish National Employment Agency (ISKUR). Both public and private vocational programs average approximately 340 hours over 3 months. They find that being assigned to training leads to a positive but insignificant effect on overall employment (2\%) and income (5.6\%) one year after completing training.

However, it is important to distinguish between untargeted, long-term, formal vocational education programs and less formal programs targeted at unemployed youth which last only a few 
months at a time. ${ }^{4}$ In contrast to the other studies mentioned above, Hicks et al. (2013) examine formal in-school technical and vocational programs that last more than a year in Kenya. They randomly provided vouchers worth US\$460 to cover all (or almost all) of the tuition costs for private and government programs. The sample consisted of 2,160 out-of-school Kenyan youths between 18 and 30 years of age; the majority (78\%) chose courses of 2 years or more, while $20 \%$ chose courses of 1 year or less. There is mixed evidence that the program affected total earnings with negative impacts several months after completing training but positive impacts a year later (which are only significant in some specifications). There is also some evidence of a significant increase in wage earnings among those who earned wages.

Another study by Bettinger, Kremer, and Saavedra (2007) examines students who applied to vocational schools through the PACES program which provided over 125,000 pupils in Colombia with vouchers for private secondary school. They find large positive impacts on educational outcomes for winners of the lottery and suggest that one possible channel may be the greater nimbleness of private vocational schools in adapting to labor market needs. Finally, there has been some research in the United States showing the effectiveness of career academies which provide vocational training to students in secondary school (Kemple and Snipes, 2000; Cullen et al., 2005).

Our study stands out in terms of its breadth of scope and its intensive data collection effort. We follow three separate cohorts of applicants for up to 4 years after completion of their vocational training. This is an important contribution of our paper since we can examine how our estimates

\footnotetext{
${ }^{4}$ In addition, there are several randomized evaluations of specialized vocational and apprenticeship programs in developing countries. These include programs that provided tailoring courses to women in the slums of New Delhi, India (Maitra and Mani, 2012), training on livestock management to women in Bangladesh (Bandiera et al., 2013), training for Ugandan women to run small businesses (Bandiera et al., 2014), apprenticeships to youth in Malawi (Cho et al., 2013), and cash grants to fund businesses or training in Uganda (Blattman, Fiala, and Martinez, 2013).
} 
are affected by fluctuations in the business cycle, which cannot be done in that examine only one cohort. ${ }^{5}$ Our results suggest that variation in the business cycle has large effects on the estimated returns to vocational education. Thus, in addition to variation in the length and quality of vocational programs, another explanation for the differences in the literature are that they are estimated in very different market conditions.

\section{Background: Vocational Education in Mongolia}

During the socialist era, Mongolia had a robust Technical Vocational and Education Training (TVET) program fashioned after the Soviet model and supported by the Soviet Union. The Mongolian TVET sector had the capacity to produce sufficient skilled labor not only for industries in Mongolia but also for other parts of the Soviet Union. As Mongolia transitioned to a market economy in the 1990s, the TVET sector deteriorated without financial and technical support from Russia. Training equipment became outdated and teachers fell behind the newest developments in their trades. At the same time, the demand for skilled labor grew as Mongolia experienced substantial economic growth due to a booming mining sector as well as new sectors such as the processing industry and construction.

The Mongolian government recognized the lack of skilled workers and inadequate capacity of TVET institutions to produce such workers. It set goals to increase TVET school enrollment and improve the quality of TVET education as part of the Second Education Master Plan 20062015. As the government became more focused on the TVET system and the need for skilled labor

\footnotetext{
${ }^{5}$ Oyer (2006), Kahn (2010), and Oreopoulos (2012) show that initial labor market conditions matter importantly for the short and long-run labor market outcomes.
} 
became more apparent as the mining sector grew and modernized, a number of international donors began to participate in making Mongolian technical and vocational education more relevant to a rapidly evolving labor market.

In 2008, the Millennium Challenge Corporation (MCC) became a major donor in the TVET sector. ${ }^{6}$ From 2008 to 2013 MCC, acting through the Millennium Challenge Account-Mongolia (MCA-M) Vocational Education Training (VET) Project, implemented wide-ranging measures to bring Mongolia's TVET sector up to international standards. The VET Project initiated institutional reforms, created competency-based curricula for prioritized trades, retrained teachers, introduced labor market information systems and career counseling and upgraded training equipment and physical infrastructures at select TVET institutions.

TVET schools in Mongolia can be either private or state-owned. Since 2012, state-owned schools have been under the authority of the Ministry of Labor which appoints the school directors and deputy directors, in charge of day to day operations. Private schools have their directors appointed by their board members. Private schools generally have the same internal structure as state-owned schools and are subject to most of the same rules, regulations and subsidies as stateowned schools. In general, there are two types of vocational education training programs available to students who have completed basic education in Mongolia: a 2/2.5-year program for students that have only completed nine years of studies in the national education system and a 1-year program for student who have completed all 11 years of secondary schooling. The 1-year programs concentrate solely on vocational training and students receive a vocational education certificate upon graduation. The 2/2.5-year programs offer a mix of basic academic courses and vocational

\footnotetext{
${ }^{6}$ See MCC $(2007,2009,2013,2014)$ on MCC's Mongolia Compact, Other key donors include the Asian Development Bank (ADB), German Gesellschaft für Internationale Zusammenarbeit (GIZ) and the Nordic Development Fund.
} 
training, and students receive both a secondary education and a vocational education certificate upon graduation.

\section{Experimental design}

The study sample comprises all applicants to 10 Mongolian TVET schools. These schools were not randomly chosen and were not a representative sample of all 76 TVET schools in Mongolia at the time of the study. In order to have randomized admission, schools that were recruited as part of the study had to have an applicant pool that was larger than the number of available admission slots. Thus, these schools were likely more competitive than the typical TVET institution in Mongolia. There were a total of 12 oversubscribed schools that were identified as potential partners for this study. All 12 schools were approached and ultimately 10 of the oversubscribed schools decided to participate in the study.

Lotteries were held in every one of the 10 TVET Evaluation schools during both the spring and fall rounds of admission over three consecutive years. Most lotteries were held as public events, open to applicants and other interested parties. ${ }^{7}$ Each of the schools set the minimum criteria that applicants must meet to be considered qualified for admission and thus eligible to be included in the lottery. ${ }^{8}$ Some schools also expressed the desire to guarantee admissions for highly qualified applicants that met certain criteria. In other cases, schools requested that applicants with guaranteed employment after graduation and disabled and disadvantaged applicants be granted a

\footnotetext{
${ }^{7}$ In accordance with their internal policies and preferences, some schools decided to hold them as closed events in the MCA-M office in Ulaanbaatar.

${ }^{8}$ Schools also had specific minimum criteria for applicants to certain trades. For example, some schools required that applicants were of a certain age to be admitted to trades that were particularly physically demanding.
} 
preferred status for admissions. All students identified by the schools as "preferred applicants" were guaranteed admission.

Applicants who participated in a spring admissions round were not eligible for the fall admissions round lottery at the same school, and participants of a lottery at one school were also not allowed to participate in a lottery at another evaluation school. . We prepared a computer program that randomly assigned applicants into trade slots based on how they had ranked their trade preferences on the application form. For example, if there were three applicants eligible for the lottery who put down construction as their first ranked trade but only two spaces were available, the computer program randomly assigned two out of the three applicants to the construction trade. The remaining applicants then went through the same process for her second ranked trade and so on. The higher students ranked a trade, the higher their probability of being accepted to that trade.

Lottery observers witnessed each of the lottery computer program's steps on a projection screen to ensure transparency. Everyone in attendance was walked through each lottery step during the event. After every step, a hard copy was printed and signed to verify and document the process. At the end of the process, the lists of trades with accepted students and the list of rejected students were provided to the school officials responsible for publicizing the lottery results.

Overall, 12,806 prospective students applied to one of the 10 schools participating in the study. Of these, 556 applicants did not meet the minimum requirements for any of the trades to which they applied, and 526 met the requirements for guaranteed automatic admission. As a result, the lotter determined the admissions status of 11,724 applicants. 


\section{Data}

The main data used for this study come from Admissions surveys in 2010, 2011 and 2012 and annual Tracking and Graduate Follow-Up (GFU) surveys from 2012-2015. The Admissions survey recorded basic social, economic and demographic characteristics and contact information of students. It also served as the application form for the 10 schools that participated in the study and included a general knowledge test to measure skill levels and academic performance. The GFU survey was administered in-person, approximately 6 to 12 months after students were expected to graduate from their respective programs, and served as the primary instrument to capture post-graduation labor market and educational outcomes. It included information on enrollment, attendance and graduation information on up to three schools they attended over the last 18 months, as well as information on short-term and longer-term employment. The survey also included trade-specific skill tests in their first and second ranked trades, intended to measure changes in skill level due to studying a trade at a TVET school. The Tracking surveys were an abbreviated version of the GFU survey that were administered by phone and used to keep track of students' outcomes before and after the main GFU survey. Table 1 below shows the full sample of tracking and GFU respondents expected to be interviewed during each year of data collection.

Table 1. Respondents to be interviewed by program, year and type of survey

\begin{tabular}{|c|c|c|c|c|c|c|c|c|c|}
\hline \multirow[b]{2}{*}{ Cohort } & \multirow[b]{2}{*}{ Program } & \multicolumn{2}{|c|}{$\begin{array}{c}2012 \\
\text { Wave } 1\end{array}$} & \multicolumn{2}{|c|}{$\begin{array}{c}2013 \\
\text { Wave } 2\end{array}$} & \multicolumn{2}{|c|}{$\begin{array}{c}2014 \\
\text { Wave } 3\end{array}$} & \multicolumn{2}{|c|}{$\begin{array}{c}2015 \\
\text { Wave } 4\end{array}$} \\
\hline & & GFU & Tracking & GFU & Tracking & GFU & Tracking & GFU & Tracking \\
\hline \multirow{2}{*}{2010} & 1 year & 524 & - & 524 & - & - & 524 & - & 524 \\
\hline & 2-2.5 year & - & 4,526 & 4,526 & - & - & 4,526 & - & 4,526 \\
\hline \multirow{2}{*}{2011} & 1 year & - & - & 335 & - & - & 335 & - & 335 \\
\hline & 2-2.5 year & - & - & - & 3,508 & 3,508 & - & - & 3,508 \\
\hline \multirow{3}{*}{2012} & 1 year & - & - & - & - & 348 & - & - & 348 \\
\hline & 2-2.5 year & - & - & - & - & & 2,999 & 2,999 & - \\
\hline & & 524 & 4,526 & 5,385 & 3,508 & 3,856 & 8,384 & 2,999 & 9,241 \\
\hline
\end{tabular}


Note that students who applied to 1-year programs in 2010 completed the GFU survey a second time in Wave 2, after changes to the survey instruments after Wave 1. As a result, the analysis of GFU surveys focused on data from Waves 2-4.

\subsection{Survey response}

The response rate was calculated by dividing the number of respondents successfully interviewed in each round of data collection by the sample of respondents that IPA intended to interview. ${ }^{9}$ Table 2 shows the response rate by survey type and wave:

Table 2. Response rates by survey type and wave

\begin{tabular}{llcccc}
\hline & & $\begin{array}{c}\text { Sample sent to } \\
\text { Surveyor by IPA }\end{array}$ & $\begin{array}{c}\text { Successfully } \\
\text { Surveyed }\end{array}$ & $\begin{array}{c}\text { Response Rate } \\
\text { by Survey (\%) }\end{array}$ & $\begin{array}{c}\text { Response Rate } \\
\text { by Wave (\%) }\end{array}$ \\
\hline \multirow{2}{*}{ Wave 2 } & GFU & 5,264 & 4,958 & $94.2 \%$ & \multirow{2}{*}{$94.8 \%$} \\
& Tracking & 3,447 & 3,303 & $95.8 \%$ & \\
\hline \multirow{2}{*}{ Wave 3 } & GFU & 3,651 & 3,334 & $91.3 \%$ & \multirow{2}{*}{$92.0 \%$} \\
& Tracking & 7,957 & 7,342 & $92.3 \%$ & \\
\hline \multirow{2}{*}{ Wave 4 } & GFU & 2,923 & 2,696 & $92.2 \%$ & \multirow{2}{*}{$88.2 \%$} \\
& Tracking & 8,570 & 7,442 & $86.8 \%$ & \\
\hline
\end{tabular}

For the Graduate Follow-Up and Tracking survey waves 2, 3 and 4, the response rate was consistently above $90 \%$, with the exception of the last tracking round which had a rate of about $87 \%$. For the fourth and final wave of Tracking and Graduate Follow-Up, 10,138 respondents were interviewed. The original admissions surveys were taken by 11,973 non-duplicate students who were eligible for the lottery and applied to a 2 or 1-year program. This translates into a response rate of $84.7 \%$ after up to five years of interview rounds. Of the 11,973 admissions baseline

\footnotetext{
${ }^{9}$ The sample of respondents sent by IPA included all students in the baseline sample except students who had previously refused to be interviewed or were deceased.
} 
respondents, 10,950 , or $91.2 \%$, were administered the study's main instrument, the Graduate Follow-Up survey, in 2013, 2014 or 2015.

\subsection{Main outcomes}

We consider four main educational outcomes that are derived from the GFU survey which took place in the year following the expected graduation of students from their TVET programs: (a) studying at a TVET school, (b) graduating from any TVET school, (c) months enrolled in any TVET school, and (d) months enrolled in any educational program. In addition, we use the corresponding educational outcomes from the Tracking survey to generate cumulative measures of educational attainment over time.

We consider four alternative measures of employment that are derived from GFU and Tracking surveys: (1) currently employed in a paid job longer than 1 month, (2) ever employed in a paid job longer than 1 month, (3) ever employed in a paid job of any length, and (4) ever employed in a paid or unpaid job of any length. ${ }^{10}$ Employment in paid jobs that last longer than 1 month are likely to represent more stable attachments to the labor market. Therefore, we view these outcomes as more valuable ones. However, there is also value in employment more generally, whether paid or unpaid, so we present these broader measures of labor market participation as well.

We also consider four measures of earnings that are derived from GFU and Tracking surveys: (1) monthly earnings if currently employed, (2) monthly earnings in most recent job, (3) average monthly earnings to date, and (4) total earnings to date. ${ }^{11}$ These are all measures of

\footnotetext{
${ }^{10}$ All these outcomes are based on employment questions pertaining to the 18-22 months prior to the GFU survey.

${ }^{11}$ All earnings measures are expressed in 2015 MNT to make them comparable across cohorts and over time. We winsorize earnings by censoring observations in the top 1 percent of the earnings distribution for each cohort. Our findings are qualitative unchanged if we include all earnings observations.
} 
earnings associated with stable paid jobs of one month and longer ${ }^{12}$. There are advantages and disadvantages to each measure. For example, one's monthly earnings if currently employed reflects the most up-to-date earnings at the time of the survey but also incorporate differences in current employment rates across respondents. On the other hand, total earnings includes all earnings to date but may be less informative about future prospects because they can be unduly influenced by past earnings. We regard the monthly earnings in the most recent job and the average monthly earnings as likely the most informative outcomes, but we show impacts on them all.

\section{Empirical strategy}

\subsection{Estimating the Impact of Admission}

We estimate the impact of admission to a TVET school using the following regression model estimated via ordinary least squares (OLS)

$$
y_{i j l m}=\beta^{\prime} X_{i}+\alpha A d m i t t e d T V E T_{i}+f\left(p_{i}^{T V E T}\right)+\mu_{j l m}+\varepsilon_{i j l m}
$$

The variable $y_{i j l m}$ is an outcome such as employment or earnings for student $i$ in school $j$ participating in round $l$ of the lottery for cohort $m$. AdmittedTVET $i$ is an indicator variable for whether or not a student $i$ was admitted to a TVET school through the lottery. The coefficient of interest in this regression is $\alpha$ which captures the difference in outcomes for students who were admitted to a TVET school compared to those students who were not admitted, after controlling for the probability of admission to a TVET school and the fixed effects for each lottery round by school and cohort. This is the causal impact of being admitted to a TVET school on outcome $y$. Because treatment with a 1-year program is likely to be different from the treatment with a 2 or

\footnotetext{
${ }^{12}$ Including earnings from jobs of less than one month makes almost no difference to any of our resulting estimates.
} 
2.5 year program, we will generally estimate the impact of admission to a TVET school separately by program.

The function $f\left(p_{i}^{T V E T}\right)$ is a polynomial of the probability that student $i$ was admitted to a TVET school given their, and their peers', preferences across trades. This function effectively controls for any differences in student characteristics associated with different preferences among trades as expressed in the rankings submitted during the application process. For this analysis, we use a cubic polynomial but the results are robust to using alternative polynomial functions. ${ }^{13}$ The probabilities were estimated empirically based on 10,000 iterations of the actual lottery algorithms used to assign students in the admissions process. ${ }^{14}$ The function also includes indicator variables for students who were guaranteed admissions (either because their most preferred trade was not oversubscribed or because they met schools' criteria for preferential treatment) and for students who had no chance of being admitted (because they did not meet the minimum requirements for any of the trades to which they applied) ${ }^{15}$

The vector of indicator variables $\mu_{j l m}$ represents fixed effects for each round of the lottery by school and cohort. Each lottery represents a separate randomized experiment. The inclusion of the fixed effects enables us to estimate the treatment effects for each lottery and then average these effects across the different lotteries. We implement these fixed effects by including indicator variables for each round of the lottery.

Finally, $X_{i}$ is a vector of baseline controls that includes a constant and can also include demographic information and baseline test scores from the admissions survey. In our preferred

\footnotetext{
${ }^{13}$ Our results are essentially unchanged when using linear, quadratic, and $10^{\text {th }}$ order polynomial functions of the probability of admission. We have also considered specifications which interact this polynomial function with indicators for cohort or program and the results are similar.

${ }^{14}$ Abdulkadiroglu et al. (2015) discuss the use of lotteries within school assignment procedures to estimate causal impacts and consider alternative approaches for estimating probabilities of admission to schools.

${ }^{15}$ Our results are unchanged if we omit students guaranteed admission and those with no chance of admission.
} 
specifications, we do not include any baseline controls for the sake of parsimony. However, because our baseline controls are balanced between students admitted and not admitted to TVET schools, the inclusion or exclusion of baseline controls does not affect the magnitude of our estimates. The standard errors in these and all subsequent regressions are adjusted for heteroscedasticity, following Abdulkadiroglu et al. (2015) as well as studies utilizing charter school lotteries for estimating causal impacts (e.g. Dobbie and Fryer, 2015; Hoxby and Rockoff, 2004). ${ }^{16}$

\subsection{Internal validity}

We conducted a series of statistical tests on the key socioeconomic and demographic variables collected in the admissions survey to test whether the lottery process was successful in producing a group of admitted students who look similar, on average, to those who were rejected. Specifically, we estimated equation (1) by replacing the outcome variables with baseline characteristics instead. After adjusting for the probability of admission related to the rankings submitted during the application process and including fixed effects, we found little evidence that students who were admitted had significantly different characteristics from those students who were not admitted. These results imply that the lotteries were successful, and that comparing across this group of applicants allows for a causal estimate of the impact of attending an evaluation school (see Appendix Table 1).

We also examined the possibility of differential attrition between students who were admitted and those who were not admitted to a TVET school after adjusting for the probability of admission. We find that students who were admitted to a TVET school were about 2.6 percentage points more likely to respond to the GFU survey (see Appendix Table 2). While these

\footnotetext{
${ }^{16}$ Most of our results remain significant if we cluster our standard errors at the level of each lottery (i.e. lottery round by school by cohort) with exceptions mentioned in the relevant sections.
} 
differences are statistically significant, they are not particularly large in magnitude. Moreover, as confirmed in the "balance tests" described above, this differential attrition did not lead to any major differences in the baseline characteristics of students who were admitted and not admitted to a TVET school (see Appendix Table 3$) \cdot{ }^{17}$

In addition, we conducted a formal analysis of compliance with the lottery results. We observe that students admitted to a TVET school are 50 percentage points more likely to graduate from their assigned school than those not admitted, and 25 percentage points more likely to graduate from their first ranked trade. These results indicate that, while compliance with the lotteries was not perfect, there are sufficient differences between groups to enable estimation of impacts (see Appendix Tables 4 and 5).

\section{Results}

We begin by examining the impact of admission to a TVET school on educational outcomes, followed by an analysis of the impact on employment and earnings. We then consider the effects on intermediate outcomes which may explain possible pathways for our estimates on labor market outcomes. We will also show separate impacts by gender because men and women are likely to experience the labor market differently, and by cohort in order to account for different conditions upon entry to the labor market. Finally, we will often restrict attention to applicants to 2-year vocational programs since we do not have sufficient sample sizes to examine 1-year programs separately.

${ }^{17}$ We also estimated these "balance tests" on baseline variables using the full sample with similar results. An alternative approach to deal with attrition would be to construct Lee-bounds. 


\subsection{Impacts on Education}

Table 3 shows the impact of admission to a TVET evaluation school on education overall and by type of program (1 year or 2-year). ${ }^{18}$ Applicants to 2-year programs who were admitted to a TVET evaluation school were significantly more likely to enroll and graduate from a TVET school. Applicants who were admitted to 2-year programs were 19 percent more likely to enroll in a TVET school and 29 percent more likely to graduate from a TVET school compared to those who were not admitted. On average, they also received 3 additional months of vocational training over those who were not admitted. The differences in the number of months enrolled in any educational program was substantially lower at only 0.6 months because many of those not admitted did enroll in other programs.

Table 3: Impact of admission to a TVET evaluation school on education (GFU surveys)

\begin{tabular}{|c|c|c|c|c|c|}
\hline Samples & $\begin{array}{c}\text { (1) } \\
\text { Enrolled at a } \\
\text { vocational school }\end{array}$ & $\begin{array}{c}(2) \\
\text { Graduated from } \\
\text { vocational school }\end{array}$ & $\begin{array}{c}\text { (3) } \\
\text { Months enrolled in } \\
\text { vocational school }\end{array}$ & $\begin{array}{l}\text { Months enrolled in } \\
\text { any educ. program }\end{array}$ & $\begin{array}{l}\text { (5) } \\
\mathrm{N}\end{array}$ \\
\hline All & $\begin{array}{c}0.126 * * * \\
(0.0128)\end{array}$ & $\begin{array}{c}0.150 * * * \\
(0.0137)\end{array}$ & $\begin{array}{c}2.945^{* * *} \\
(0.277)\end{array}$ & $\begin{array}{c}0.0606^{* * * *} \\
(0.0124)\end{array}$ & 10,950 \\
\hline Percentage impact & $19.8 \%$ & $28.6 \%$ & $23.6 \%$ & $8.6 \%$ & \\
\hline 2-year & $\begin{array}{c}0.127 * * * \\
(0.0130)\end{array}$ & $\begin{array}{l}0.153^{* * *} \\
(0.0140)\end{array}$ & $\begin{array}{c}3.005^{* * *} \\
(0.285)\end{array}$ & $\begin{array}{c}0.0620 * * * \\
(0.0126)\end{array}$ & 9,878 \\
\hline Percentage impact & $19.3 \%$ & $28.5 \%$ & $23.4 \%$ & $8.6 \%$ & \\
\hline 1 year & $\begin{array}{c}0.118^{*} \\
(0.0628)\end{array}$ & $\begin{array}{c}0.0696 \\
(0.0618)\end{array}$ & $\begin{array}{l}1.284^{*} \\
(0.779)\end{array}$ & $\begin{array}{c}0.0202 \\
(0.0712)\end{array}$ & 1,072 \\
\hline Percentage impact & $40.4 \%$ & $25.7 \%$ & $33.2 \%$ & $5.1 \%$ & \\
\hline
\end{tabular}

The educational impacts for applicants to 1-year programs are mostly smaller and less significant, although the effect on enrollment is not substantially different. The absence of significant effects for 1-year programs is a direct consequence of the smaller samples sizes which makes it more

\footnotetext{
${ }^{18}$ All of the subsequent tables show standard errors in parentheses and use the usual notation to indicate significance at the corresponding levels of the $\mathrm{p}$-values: ${ }^{* * *} \mathrm{p}<0.001,{ }^{* *} \mathrm{p}<0.05,{ }^{*} \mathrm{p}<0.01$.
} 
difficult to ascertain program impacts with confidence. Moreover, the impacts for the full sample are extremely similar to those for 2-year programs because the sample size is substantially larger than for 1-year programs. Consequently, in the subsequent tables which consider impacts separately by cohort and gender, we focus only on applicants to 2-year programs.

We also consider the differential impacts of admission to 2-year TVET programs on education by cohort. The impacts are fairly similar across cohorts, albeit slightly smaller for the 2010 cohort. In Figure 1 and Figure 2 below, we show the cumulative enrollment and graduation rates from vocational schools at 6-month intervals by cohort for applicants who were admitted and rejected by the lottery:

Figure 1. Cumulative enrollment rates from vocational school by cohort (2-year programs)

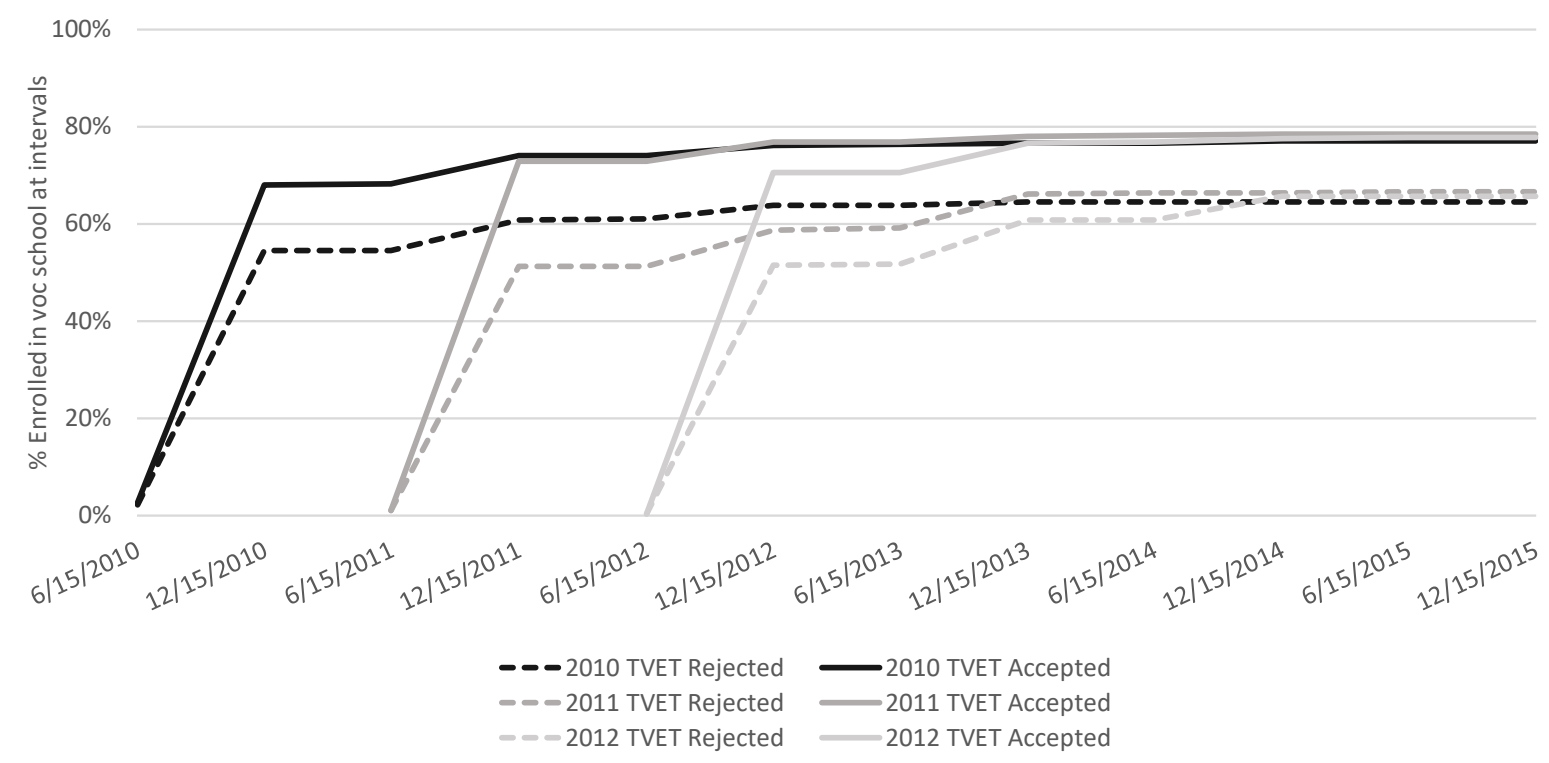


Figure 2. Cumulative graduation rates from vocational school by cohort (2-year programs)

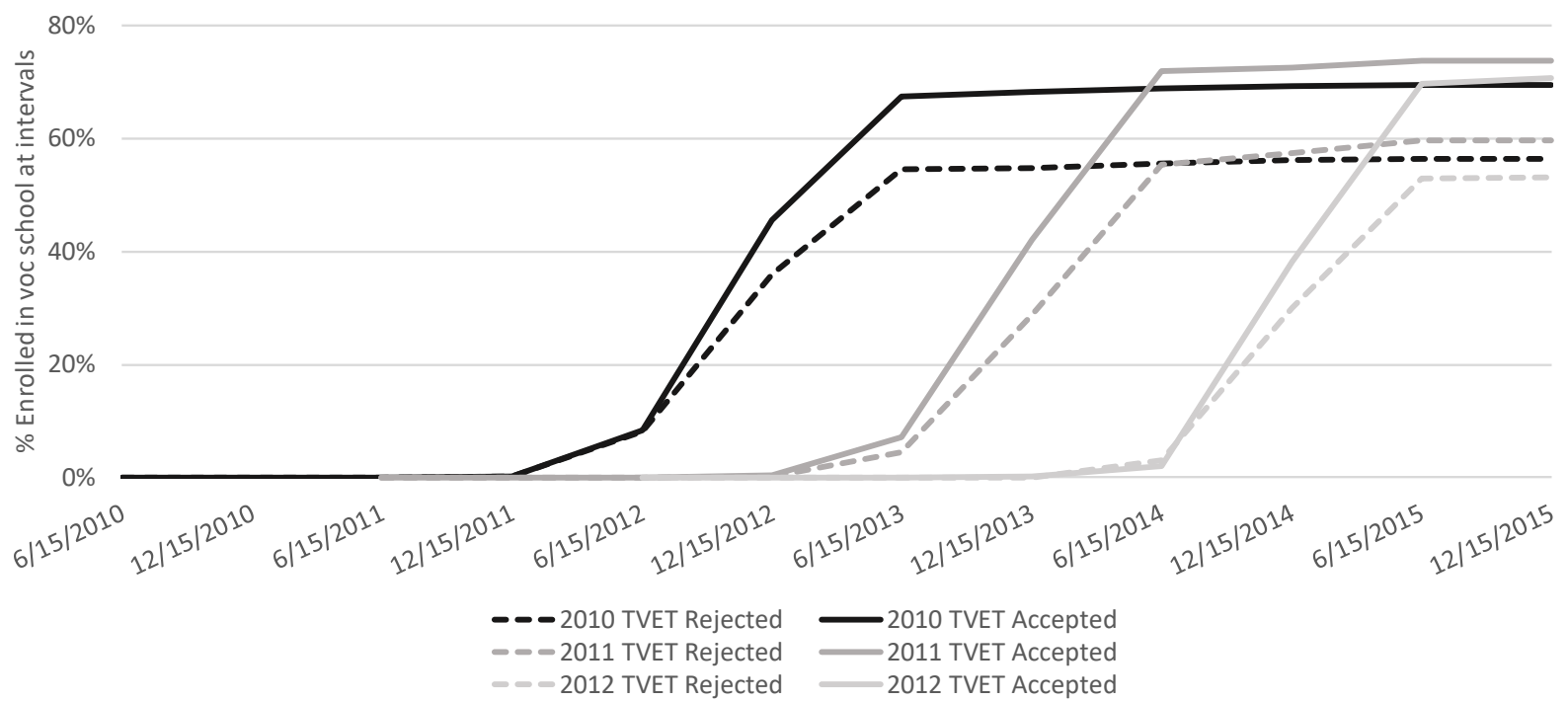

We observe the increase in enrollment in vocational schools almost immediately after admission to TVET programs while the increase in graduation appears about two years after admission. For both measures, there are clear and persistent differences between applicants admitted and rejected by the lottery in subsequent months.

The patterns of enrollment in any educational program differ markedly from the enrollment specifically in vocational schools. When we compare enrollment rates for admitted and non-admitted individuals over time in Figure 3, we see that admitted students are more likely to be enrolled during the 2 years following admission, at which point the pattern reverses with those non-admitted more likely to be enrolled subsequently. Eventually, the enrollment rates converge and the differences between admitted and non-admitted individuals become small. 
Figure 3. Current enrollment in any education program by cohort (2-year programs)

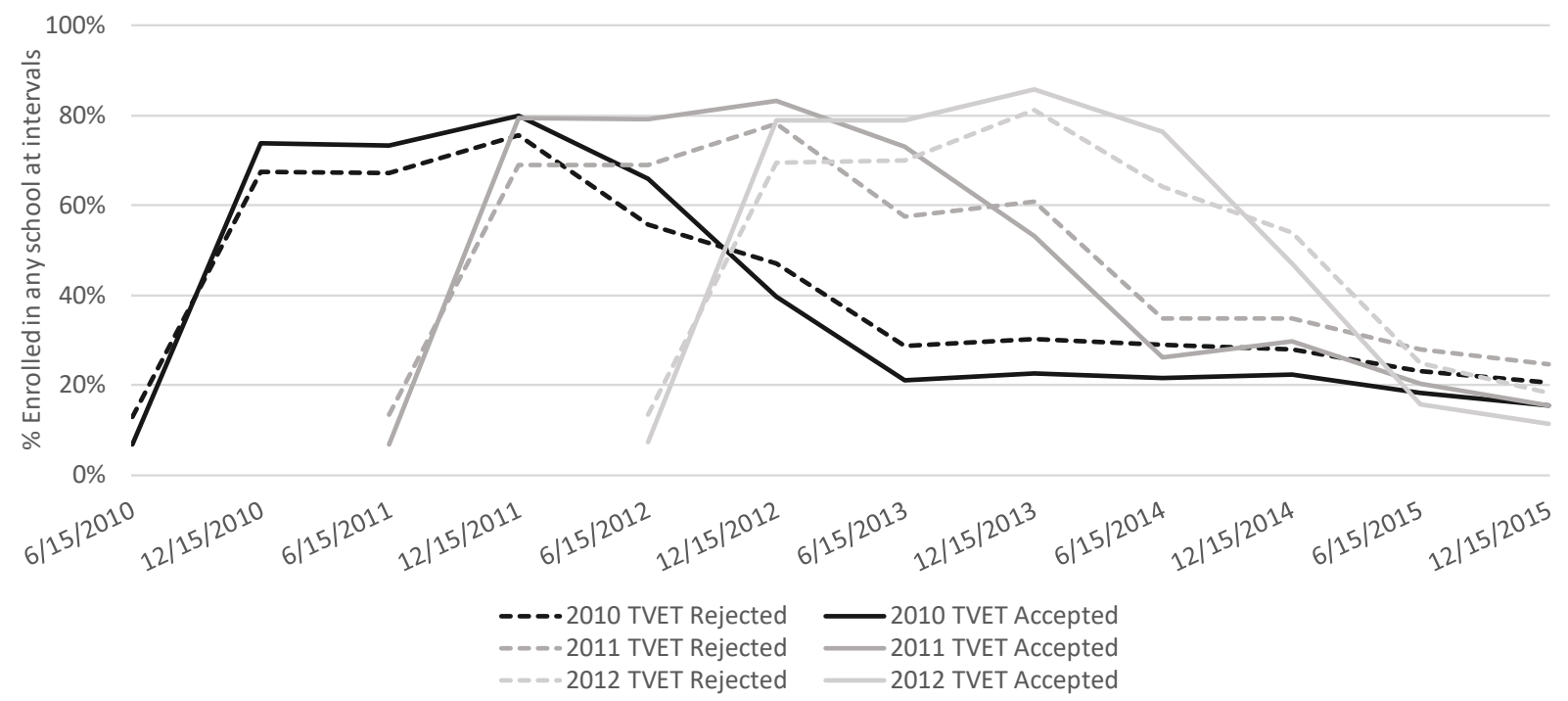

If we calculate cumulative enrollment rates, as in Figure 4, we see that admitted students are always more likely to be enrolled than those non-admitted but essentially convergence by the third year following admission.

Figure 4. Cumulative enrollment in any education program by cohort (2-year programs)

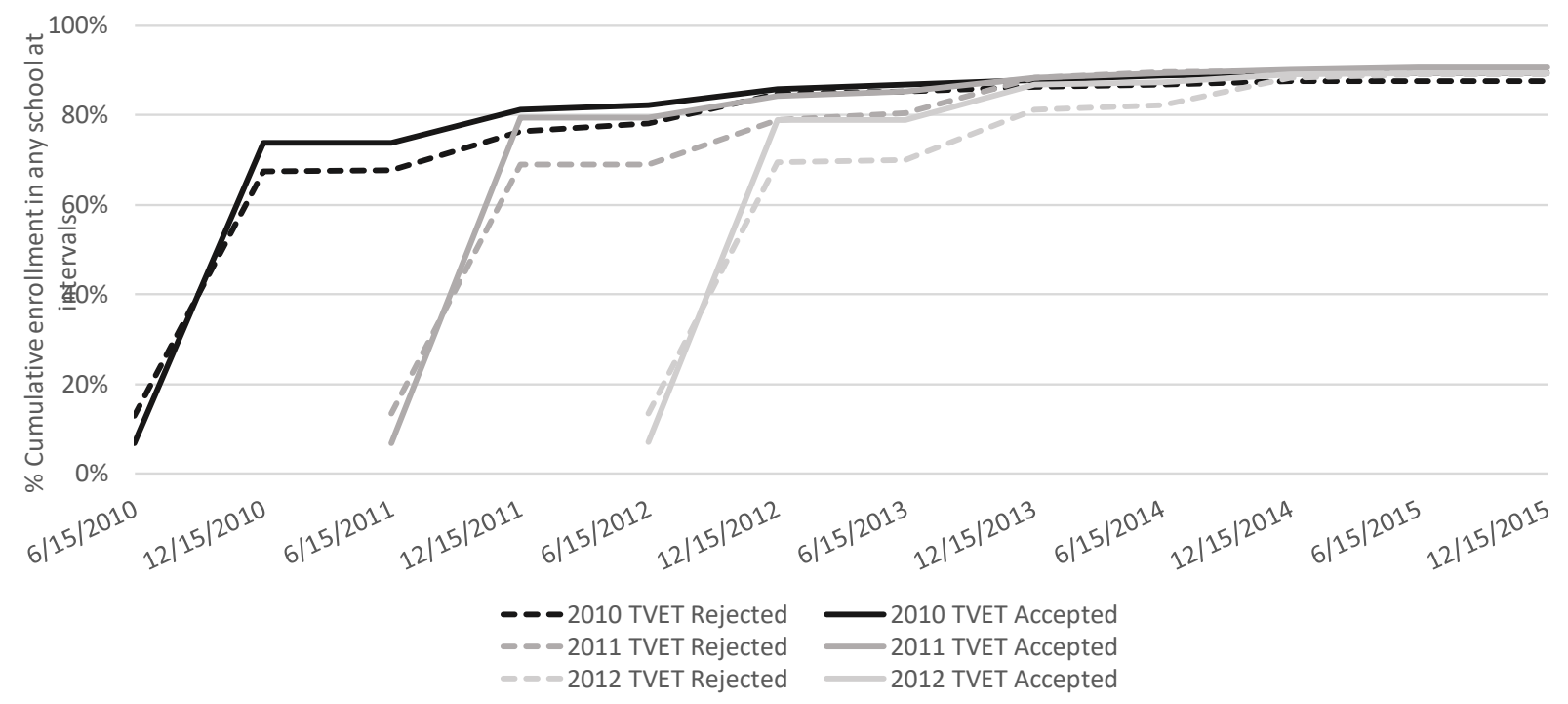


The estimated impacts on education outcomes are markedly different by gender. As shown in Table 4 below, the impact of admission to 2-year programs is almost twice as large for females as for males across all our educational outcomes:

Table 4. Impact of admission to a TVET school on education by gender (GFU; 2-year programs)

\begin{tabular}{|c|c|c|c|c|c|}
\hline Samples & $\begin{array}{c}(1) \\
\text { Enrolled in a } \\
\text { vocational school }\end{array}$ & $\begin{array}{c}(2) \\
\text { Graduated from } \\
\text { vocational school }\end{array}$ & $\begin{array}{c}(3) \\
\text { Months enrolled in } \\
\text { vocational school }\end{array}$ & $\begin{array}{l}(4) \\
\text { Months enrolled in } \\
\text { any educ. program }\end{array}$ & $\begin{array}{l}(5) \\
\mathrm{N}\end{array}$ \\
\hline Males & $\begin{array}{c}0.0945^{* * *} \\
(0.0170)\end{array}$ & $\begin{array}{c}0.118^{* * *} \\
(0.0185)\end{array}$ & $\begin{array}{c}2.221^{* * *} \\
(0.374)\end{array}$ & $\begin{array}{c}0.0503^{* * *} \\
(0.0169)\end{array}$ & 5,995 \\
\hline Percentage impact & $13.9 \%$ & 21.1\% & $16.6 \%$ & $7.0 \%$ & \\
\hline Female & $\begin{array}{c}0.174 * * * \\
(0.0203)\end{array}$ & $\begin{array}{c}0.204^{* * *} \\
(0.0215)\end{array}$ & $\begin{array}{c}4.152^{* * *} \\
(0.441)\end{array}$ & $\begin{array}{c}0.0783^{* * *} \\
(0.0190)\end{array}$ & 3,883 \\
\hline Percentage impact & $28.1 \%$ & $40.1 \%$ & $34.2 \%$ & $10.9 \%$ & \\
\hline
\end{tabular}

For example, female applicants who were admitted to 2-year programs were exposed to 4.2 additional months of vocational training compared to only 2.2 additional months for their male counterparts.

To summarize the results from this section, we find strong evidence that admission to TVET evaluation schools led to significant increases in enrollment, graduation, and months of exposure to vocational education. The impacts are substantially larger for females than for males but similar across cohorts.

\subsection{Employment}

A serious challenge in examining early labor market outcomes for this population is that some individuals may still be enrolled in educational programs at the time of the survey. As shown previously, individuals who were admitted to vocational schools are less likely to be enrolled in an educational program than those who were not admitted at the time of the GFU survey. Thus, 
any impacts on current employment need to be interpreted with care. ${ }^{19}$ But given that cumulative enrollment rates are very similar for admitted and non-admitted individuals at the time of the GFU survey, measures of ever being employed are likely to be more reliable. Indeed, the number of months enrolled in any education program is even higher for admitted students than those not admitted suggesting we might have expected to observe lower employment rates among admitted students for the likelihood of being employed. Furthermore, estimates using the later tracking surveys for the 2010 and 2011 cohorts will generally be less affected by this issue.

Table 5 below shows the impacts of admissions to a TVET evaluation school for the whole sample and by program at the time of the GFU survey. Admission has a significant effect on employment for 2-year participants. Those admitted through the lottery were 4 percent more likely to be employed in a paid job and 9 percent more likely to have held a paid job lasting longer than one month.

Table 5. Impact of admission to a TVET school on employment by program (GFU surveys)

\begin{tabular}{|c|c|c|c|c|c|}
\hline Samples & $\begin{array}{c}\text { Currently } \\
\text { employed in paid } \\
\text { job }(>\mathbf{1} \text { month })\end{array}$ & $\begin{array}{l}\text { Ever employed } \\
\text { in paid job } \\
\text { (>1 month) }\end{array}$ & $\begin{array}{c}\text { (3) } \\
\text { Ever employed } \\
\text { in paid job } \\
\text { (any) }\end{array}$ & $\begin{array}{c}(4) \\
\text { Ever employed in } \\
\text { paid or unpaid } \\
\text { job (any) }\end{array}$ & $\begin{array}{l}\text { (5) } \\
\mathrm{N}\end{array}$ \\
\hline All & $\begin{array}{c}0.0357^{* * *} \\
(0.0124)\end{array}$ & $\begin{array}{c}0.0480 * * * \\
(0.0138)\end{array}$ & $\begin{array}{c}0.0292^{* *} \\
(0.0125)\end{array}$ & $\begin{array}{c}0.0601 * * * \\
(0.0105)\end{array}$ & 10,950 \\
\hline Percentage impact & $14.3 \%$ & $8.9 \%$ & 4.1\% & 7.4\% & \\
\hline 2-year & $\begin{array}{c}0.0332 * * * \\
(0.0126)\end{array}$ & $\begin{array}{c}0.0486 * * * \\
(0.0140)\end{array}$ & $\begin{array}{c}0.0303 * * \\
(0.0128)\end{array}$ & $\begin{array}{c}0.0607^{* * *} \\
(0.0107)\end{array}$ & 9,878 \\
\hline Percentage impact & $13.2 \%$ & $8.9 \%$ & $4.2 \%$ & $7.5 \%$ & \\
\hline 1 year & $\begin{array}{c}0.106 \\
(0.0651)\end{array}$ & $\begin{array}{c}0.0337 \\
(0.0730)\end{array}$ & $\begin{array}{l}0.00825 \\
(0.0655)\end{array}$ & $\begin{array}{c}0.0595 \\
(0.0565)\end{array}$ & 1,072 \\
\hline Percentage impact & $46.4 \%$ & $7.0 \%$ & $1.3 \%$ & $7.5 \%$ & \\
\hline
\end{tabular}

\footnotetext{
${ }^{19}$ As a possible robustness check for this measure, we also estimate the impact on employment for the subsample of individuals who are not currently enrolled. Of course, this sample restriction suffers from non-random selection into who chooses to enroll in an educational program.
} 
The impacts for applicants to 1-year programs are positive, with a surprisingly large magnitude for current employment in a paid job lasting longer than one month. However, as with the results for education outcomes, none of the estimates for applicants to 1-year programs are significant. As a result, all the tables that follow focus on applicants to 2-year programs.

The differential impacts of admission to 2-year programs by cohort are available by request. However, it is worth noting that the impacts on employment are large and significant for the 2010 and 2011 cohorts but essentially zero for the 2012 cohort (except for ever having been employed in a paid or unpaid job of any duration). In Figure 5 below, we show the cumulative employment rates at 6-month intervals by cohort for applicants who were admitted and rejected by the lottery:

Figure 5. Cumulative impact of admission to a TVET school on employment (2-year programs)

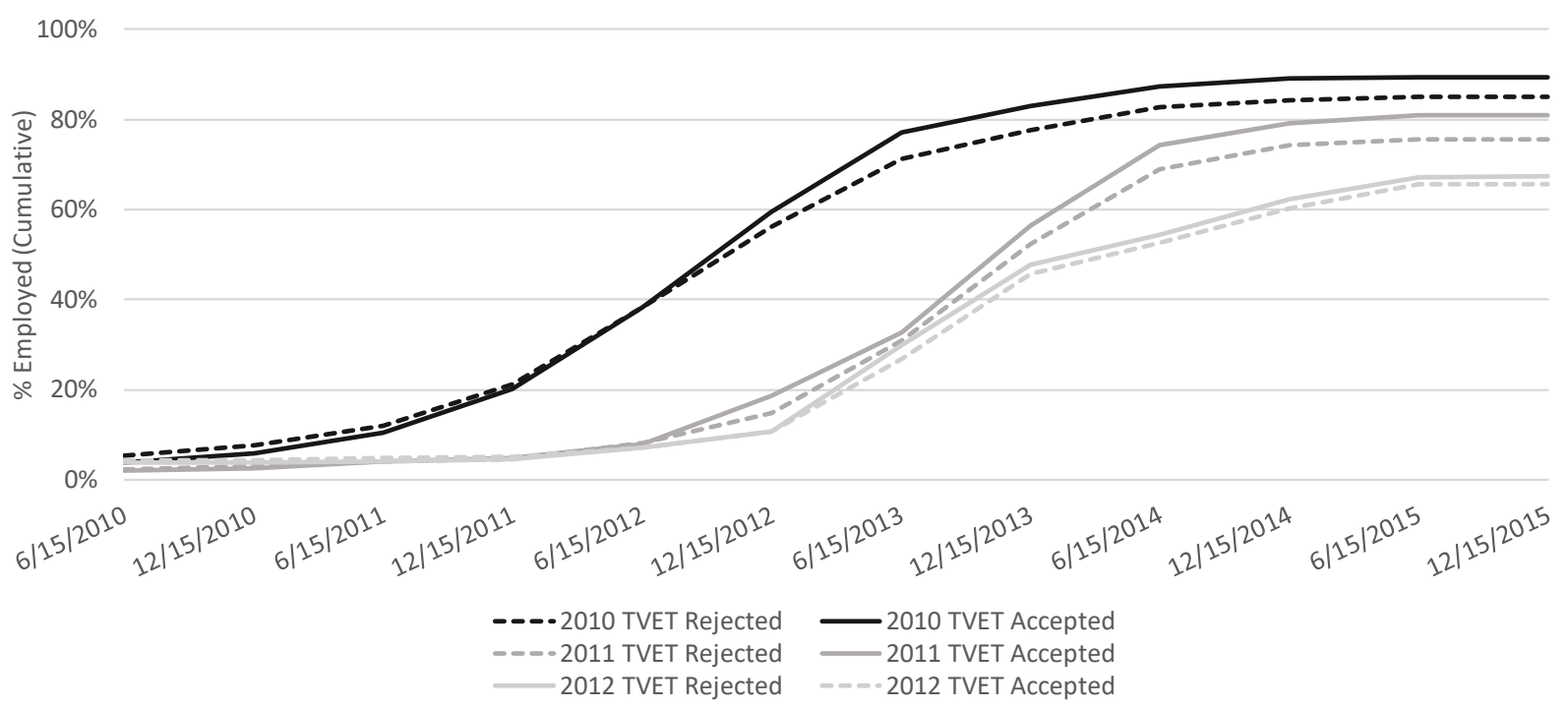

The patterns above depict a gradual increase in employment up to one year after admission to TVET programs with differences between admitted and rejected applicants appearing by the end of the period. There are also some apparent differences in both the level and differences by cohort, 
with substantial declines for later cohorts. This is confirmed in the table below showing that the large impacts on employment are driven by the 2010 and 2011 cohorts:

Table 6. Impact of admission to a TVET school on employment by cohort (GFU; 2-yr programs)

\begin{tabular}{|c|c|c|c|c|c|}
\hline Samples & $\begin{array}{c}\text { Currently } \\
\text { employed in paid } \\
\text { job }(>\mathbf{1} \text { month })\end{array}$ & $\begin{array}{l}\text { Ever employed } \\
\text { in paid job } \\
(>\mathbf{1} \text { month })\end{array}$ & $\begin{array}{c}\text { Ever employed } \\
\text { in paid job (any) }\end{array}$ & $\begin{array}{l}\text { Ever employed in } \\
\text { paid or unpaid job } \\
\text { (any) }\end{array}$ & (5) \\
\hline 2010 & $\begin{array}{c}0.0418^{* *} \\
(0.0197)\end{array}$ & $\begin{array}{c}0.0455^{* *} \\
(0.0217)\end{array}$ & $\begin{array}{c}0.0272 \\
(0.0197)\end{array}$ & $\begin{array}{c}0.0545 * * * \\
(0.0165)\end{array}$ & 4,182 \\
\hline Percentage impact & $16.3 \%$ & $8.1 \%$ & $3.7 \%$ & $6.6 \%$ & \\
\hline 2011 & $\begin{array}{l}0.0531^{* *} \\
(0.0229)\end{array}$ & $\begin{array}{c}0.0648 * * * \\
(0.0242)\end{array}$ & $\begin{array}{c}0.0528 * * \\
(0.0216)\end{array}$ & $\begin{array}{c}0.0726 * * * \\
(0.0181)\end{array}$ & 3,000 \\
\hline Percentage impact & $18.8 \%$ & $11.3 \%$ & $7.2 \%$ & $9.0 \%$ & \\
\hline 2012 & $\begin{array}{r}-0.00928 \\
(0.0231)\end{array}$ & $\begin{array}{c}0.0289 \\
(0.0285)\end{array}$ & $\begin{array}{l}0.00566 \\
(0.0264)\end{array}$ & $\begin{array}{c}0.0561 * * \\
(0.0219)\end{array}$ & 2,696 \\
\hline Percentage impact & $-4.7 \%$ & $6.1 \%$ & $0.9 \%$ & $7.1 \%$ & \\
\hline
\end{tabular}

Table 7 below shows effects on employment for 2-year programs by gender. The positive impacts of being admitted to an evaluation school through the lottery are substantially stronger for female applicants. Admitted females are 15 percent more likely to have ever been employed for longer than 1 month, whereas the (marginally significant) difference for males is just 5 percent.

Table 7. Impact of admission to a TVET school on employment by gender (GFU; 2-yr programs)

\begin{tabular}{|c|c|c|c|c|c|}
\hline Samples & $\begin{array}{c}\text { Currently } \\
\text { employed in paid } \\
\text { job }(>\mathbf{1} \text { month })\end{array}$ & $\begin{array}{c}\text { Ever employed } \\
\text { in paid job } \\
\text { (>1 month) }\end{array}$ & $\begin{array}{c}\text { Ever employed } \\
\text { in paid job (any) }\end{array}$ & $\begin{array}{l}\text { Ever employed in } \\
\text { paid or unpaid job } \\
\text { (any) }\end{array}$ & (5) \\
\hline Males & $\begin{array}{c}0.0221 \\
(0.0170)\end{array}$ & $\begin{array}{l}0.0340 * \\
(0.0183)\end{array}$ & $\begin{array}{l}0.0264 * \\
(0.0154)\end{array}$ & $\begin{array}{c}0.0502 * * * \\
(0.0126)\end{array}$ & \multirow[t]{2}{*}{5,995} \\
\hline Percentage impact & $7.7 \%$ & $5.5 \%$ & $3.4 \%$ & $5.8 \%$ & \\
\hline Female & $\begin{array}{c}0.0472^{* *} \\
(0.0185)\end{array}$ & $\begin{array}{c}0.0681^{* * *} \\
(0.0217)\end{array}$ & $\begin{array}{l}0.0363^{*} \\
(0.0214)\end{array}$ & $\begin{array}{c}0.0764^{* * *} \\
(0.0184)\end{array}$ & \multirow[t]{2}{*}{3,883} \\
\hline Percentage impact & $23.3 \%$ & $15.4 \%$ & $5.9 \%$ & $10.3 \%$ & \\
\hline
\end{tabular}


We also examined impacts using the Tracking survey in later years for applicants from the 2010 and 2011 cohorts. Table 8 below shows employment outcomes from the 2014 Tracking survey for the 2010 cohort and the 2015 Tracking survey for the 2011 cohort, to show employment outcomes one year after their respective GFU surveys:

Table 8. Impact of admission to a TVET school on later employment (tracking; 2-year progs)

\begin{tabular}{|c|c|c|c|c|c|}
\hline Samples & $\begin{array}{c}(1) \\
\text { Currently } \\
\text { employed in paid } \\
\text { job (>1 month) }\end{array}$ & $\begin{array}{c}(2) \\
\text { Ever employed } \\
\text { in paid job } \\
\text { (>1 month) } \\
\end{array}$ & $\begin{array}{c}\text { Ever employed } \\
\text { in paid job (any) }\end{array}$ & $\begin{array}{c}\text { Ever employed } \\
\text { in paid or } \\
\text { unpaid job } \\
\text { (any) }{ }^{\mathbf{i}} \\
\end{array}$ & (5) \\
\hline $\begin{array}{l}\text { All: Two years out } \\
2010 \& 2011\end{array}$ & $\begin{array}{c}0.0404^{* *} \\
(0.0165)\end{array}$ & $\begin{array}{c}0.0801^{* * *} \\
(0.0166)\end{array}$ & $\begin{array}{c}0.0747^{* * *} \\
(0.0152)\end{array}$ & $\begin{array}{l}- \\
-\end{array}$ & 6,583 \\
\hline Percentage impact & $13.1 \%$ & $12.4 \%$ & $10.3 \%$ & & \\
\hline $\begin{array}{l}\text { Male: Two years out } \\
2010 \& 2011\end{array}$ & $\begin{array}{c}0.0342 \\
(0.0230)\end{array}$ & $\begin{array}{c}0.0635^{* * *} \\
(0.0204)\end{array}$ & $\begin{array}{c}0.0624^{* * *} \\
(0.0179)\end{array}$ & $\begin{array}{l}- \\
-\end{array}$ & 3,855 \\
\hline Percentage impact & $9.5 \%$ & $8.6 \%$ & $7.7 \%$ & & \\
\hline $\begin{array}{l}\text { Female: Two years } \\
\text { out } 2010 \& 2011\end{array}$ & $\begin{array}{l}0.0462^{* *} \\
(0.0232)\end{array}$ & $\begin{array}{l}0.102 * * * \\
(0.0264)\end{array}$ & $\begin{array}{c}0.0911^{* * *} \\
(0.0253)\end{array}$ & $\begin{array}{l}- \\
-\end{array}$ & 2,728 \\
\hline Percentage impact & $19.3 \%$ & $19.1 \%$ & $14.7 \%$ & & \\
\hline
\end{tabular}

${ }^{\mathrm{i}}$ Tracking surveys did not ask about unpaid employment

The effects of being admitted to a TVET evaluation school on employment remain large and significant one year after the GFU survey, especially for females. Women were 19 percent more likely to ever have been gainfully employed for longer than 1 month, compared with 8 percent for males. Overall, applicants admitted to TVET schools were 13 percent more likely to be currently employed than those not admitted.

To summarize, there is strong evidence that admission to a TVET school leads to higher employment. While these impacts are significant for both men and women, the magnitudes are substantially larger for women, both in absolute levels and in terms of percentage impacts. There is also some evidence that impacts on employment are larger for later cohorts and grow over time. 


\subsection{Earnings}

As with employment, our estimates of earnings are likely to be affected by differences in enrollment rates between individuals who were and were not admitted to vocational schools. Again, our estimates of impacts on current earnings using the GFU survey need to be interpreted with care. On the other hand, the measures of total earnings to date and average monthly earnings to date are probably less affected and the estimates using the subsequent tracking surveys for the 2010 and 2011 cohorts will also be less affected. We begin by presenting the impact of admission to a TVET evaluation school on earnings, overall and by $\operatorname{program}^{20}$ :

Table 9. Impact of admission to a TVET school on earnings by program (GFU surveys)

\begin{tabular}{|c|c|c|c|c|c|}
\hline Samples & $\begin{array}{l}\text { (1) } \\
\text { Monthly earnings if } \\
\text { currently employed }\end{array}$ & $\begin{array}{c}\text { (2) } \\
\text { Most recent } \\
\text { monthly earnings }\end{array}$ & $\begin{array}{l}\text { Average earnings } \\
\text { per month }\end{array}$ & $\begin{array}{c}(4) \\
\text { Total } \\
\text { earnings }\end{array}$ & $\mathrm{N}$ \\
\hline All & $\begin{array}{l}19,678^{*} \\
(10,359)\end{array}$ & $\begin{array}{c}11,909 \\
(12,296)\end{array}$ & $\begin{array}{c}12,479 \\
(11,969)\end{array}$ & $\begin{array}{c}54,136 \\
(113,602)\end{array}$ & 10,950 \\
\hline Percentage impact & $12.1 \%$ & $3.4 \%$ & $3.6 \%$ & $2.5 \%$ & \\
\hline 2-year & $\begin{array}{c}17,162 \\
(10,666)\end{array}$ & $\begin{array}{r}10,333 \\
(12,652)\end{array}$ & $\begin{array}{c}10,709 \\
(12,312)\end{array}$ & $\begin{array}{c}35,681 \\
(115,706)\end{array}$ & 9,878 \\
\hline Percentage impact & $10.5 \%$ & $2.9 \%$ & $3.1 \%$ & $1.7 \%$ & \\
\hline 1 year & $\begin{array}{c}90,854^{* * *} \\
(34,264)\end{array}$ & $\begin{array}{c}59,841 \\
(42,277)\end{array}$ & $\begin{array}{c}66,142 \\
(41,299)\end{array}$ & $\begin{array}{c}659,687 \\
(574,713)\end{array}$ & 1,072 \\
\hline Percentage impact & $64.5 \%$ & $23.2 \%$ & $26.5 \%$ & $24.5 \%$ & \\
\hline
\end{tabular}

The magnitudes of the impacts are all positive, and especially large for those associated with the 1-year programs. However, none of the coefficients is significant, with the exception of marginal significance for monthly earnings if currently employed.

We have examined the differential impacts by cohort for applicants to 2-year programs but none of the coefficients are significant. Neither does Figure 6 below reveal much evidence of

\footnotetext{
${ }^{20}$ Note that we do not estimate log earnings regression as our main specification because there is a large fraction of individuals with zero earnings (which would be dropped from the sample when applying logarithms). We have estimated log earnings regression conditional on having positive earnings as well as log earnings regressions where we arbitrarily assign a 1 to observations with 0 earnings, and these results are available by request.
} 
differences in overall cumulative earnings at 6-month intervals by cohort for applicants who were admitted and rejected by the lottery:

Figure 6. Cumulative impact of admission to a TVET school on earnings (2-year programs) Cumulative earnings (GFU and Wave 4 Tracking, 2y sample)

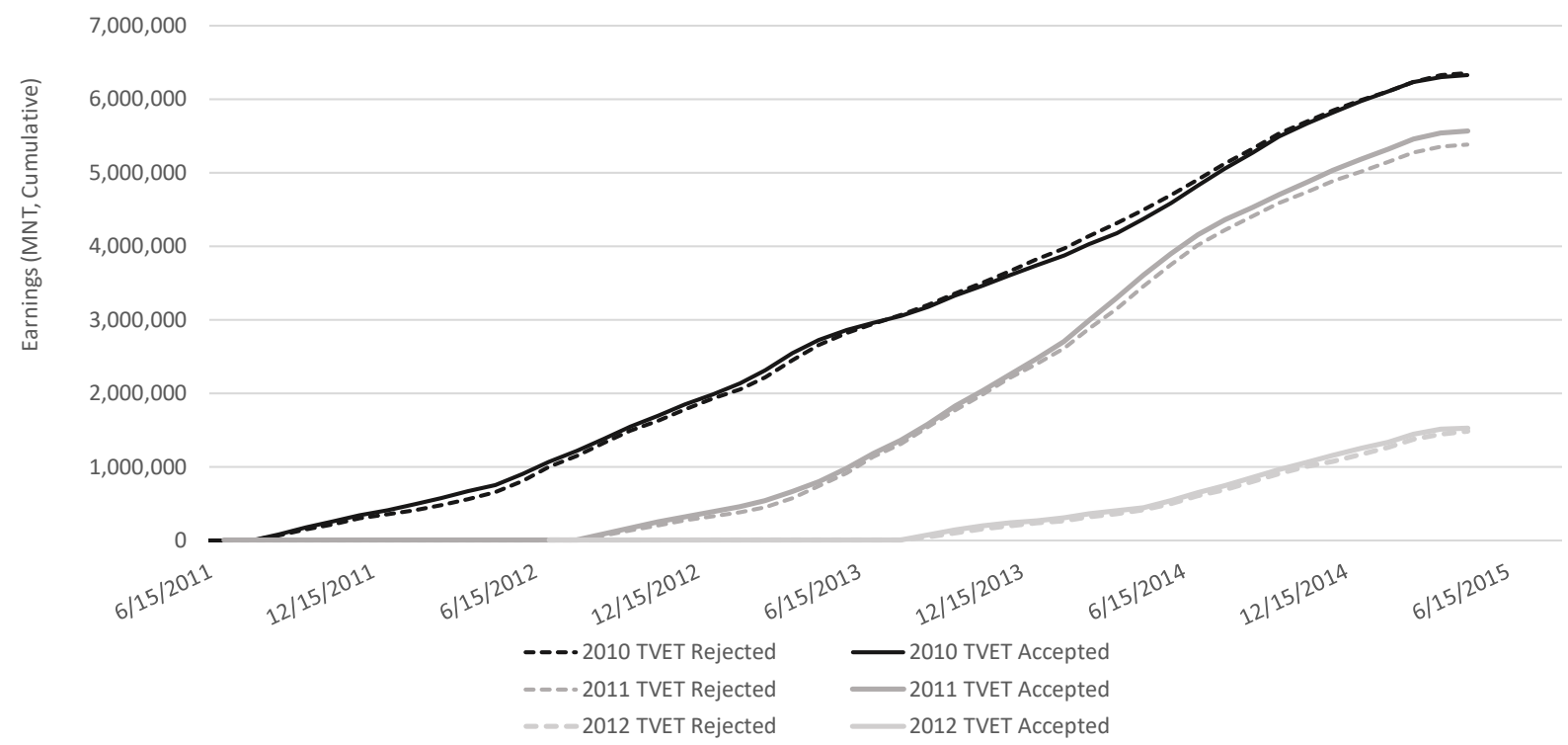

However, when we restrict the sample to females, we do observe large differences in cumulative earnings for applicants who were admitted and rejected by the lottery:

Figure 7. Cumulative impact of admission to TVET schools on female earnings (2-year) Cumulative earnings at intervals (GFU and Wave 4 Tracking, $2 y$ female sample)

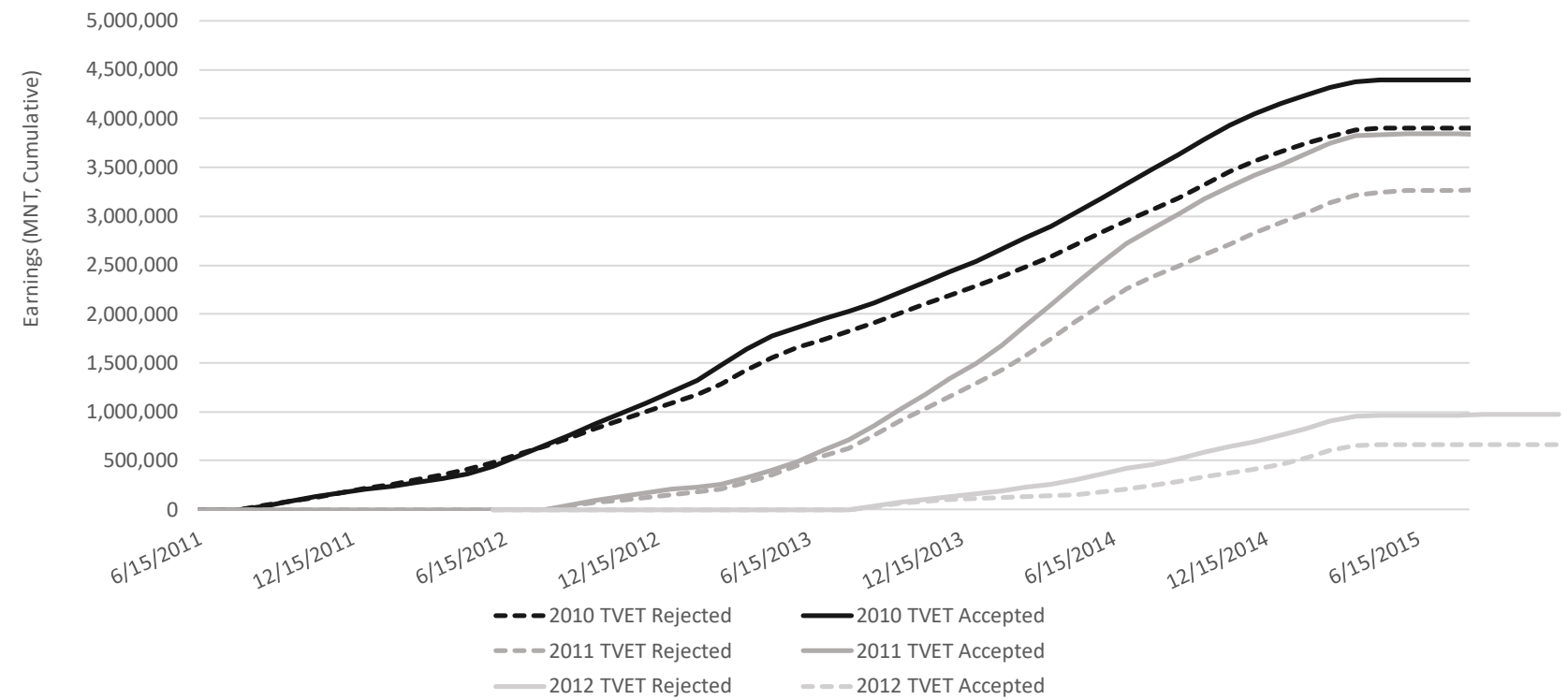


The impact of admission to 2-year programs is shown separately for males and females in 10 below. None of the estimates for men are significant and most are close to zero in terms of percentage impacts. However, the impacts are large and significant for women across the various measures of monthly earnings. Those who were admitted to a 2-year TVET program earned approximately $27,000-30,000 \mathrm{MNT}$ per month as compared to their counterparts who were not admitted. These are also substantial in percentage terms, with $13-14 \%$ higher monthly earnings in their most recent job and on average, and $27 \%$ higher monthly earnings if currently employed.

Table 10. Impact of admission to a TVET school on earnings by gender (GFU; 2-year programs)

\begin{tabular}{|c|c|c|c|c|c|}
\hline Samples & $\begin{array}{c}(1) \\
\text { Monthly earnings } \\
\text { if currently } \\
\text { employed } \\
\end{array}$ & $\begin{array}{c}\text { (2) } \\
\text { Most recent } \\
\text { monthly earnings }\end{array}$ & $\begin{array}{l}\text { Average earnings } \\
\text { per month }\end{array}$ & $\begin{array}{c}\text { (4) } \\
\text { Total } \\
\text { earnings }\end{array}$ & $\mathrm{N}$ \\
\hline Males & $\begin{array}{c}9,752 \\
(16,142)\end{array}$ & $\begin{array}{c}-3,034 \\
(18,512)\end{array}$ & $\begin{array}{c}-2,973 \\
(17,975)\end{array}$ & $\begin{array}{c}3,314 \\
(176,543)\end{array}$ & \multirow[t]{4}{*}{5,995} \\
\hline Percentage impact & $4.7 \%$ & $-0.7 \%$ & $-0.7 \%$ & $0.1 \%$ & \\
\hline Female & $\begin{array}{r}27,456 * * \\
(11,572)\end{array}$ & $\begin{array}{c}29,210 * * \\
(14,737)\end{array}$ & $\begin{array}{r}29,777^{* *} \\
(14,339)\end{array}$ & $\begin{array}{c}74,637 \\
(119,908)\end{array}$ & \\
\hline Percentage impact & $27.6 \%$ & $13.3 \%$ & $13.9 \%$ & $6.1 \%$ & \\
\hline
\end{tabular}

We also examine earnings outcomes from the Tracking survey for the 2010 and 2011 applicants to 2-year programs, overall and by gender. As with employment, these outcomes are constructed from the 2014 Tracking survey for the 2010 cohort and the 2015 Tracking survey for the 2011 cohort, to show earnings one year after their respective GFU surveys. 
$\underline{\text { Table 11. Impact of admission to a TVET school on later earnings (Tracking; 2-year programs) }}$

\begin{tabular}{|c|c|c|c|c|c|}
\hline Samples & $\begin{array}{c}\text { (1) } \\
\text { Monthly earnings } \\
\text { if currently } \\
\text { employed }\end{array}$ & $\begin{array}{c}(2) \\
\text { Most recent } \\
\text { monthly earnings }\end{array}$ & $\begin{array}{c}(3) \\
\text { Average } \\
\text { earnings per } \\
\text { month }\end{array}$ & $\begin{array}{c}\text { (4) } \\
\text { Total } \\
\text { earnings }\end{array}$ & (5) \\
\hline $\begin{array}{l}\text { All: Two years out } \\
2010 \& 2011\end{array}$ & $\begin{array}{c}17,826 \\
(13,457)\end{array}$ & $\begin{array}{c}34,602^{* *} \\
(15,634)\end{array}$ & $\begin{array}{c}23,333 \\
(15,045)\end{array}$ & $\begin{array}{c}140,987 \\
(194,084)\end{array}$ & 6,583 \\
\hline Percentage impact & $9.1 \%$ & $9.3 \%$ & $6.3 \%$ & $4.0 \%$ & \\
\hline $\begin{array}{l}\text { Male: Two years out } \\
2010 \& 2011\end{array}$ & $\begin{array}{c}5,831 \\
(21,055)\end{array}$ & $\begin{array}{c}9,116 \\
(23,989)\end{array}$ & $\begin{array}{c}-8,787 \\
(23,034)\end{array}$ & $\begin{array}{l}-178,954 \\
(300,980)\end{array}$ & 3,855 \\
\hline Percentage impact & $2.3 \%$ & $2.0 \%$ & $-1.9 \%$ & $-3.9 \%$ & \\
\hline $\begin{array}{l}\text { Female: Two years } \\
\text { out } 2010 \& 2011\end{array}$ & $\begin{array}{r}30,934^{* *} \\
(14,378)\end{array}$ & $\begin{array}{c}66,586 * * * \\
(17,038)\end{array}$ & $\begin{array}{c}64,196 * * * \\
(16,438)\end{array}$ & $\begin{array}{c}551,269 * * * \\
(207,597)\end{array}$ & 2,728 \\
\hline Percentage impact & $25.6 \%$ & $26.2 \%$ & $25.8 \%$ & $26.3 \%$ & \\
\hline
\end{tabular}

Looking one year after the GFU survey and approximately two years after students would have graduated from their 2-year programs, we see further evidence of significant impacts on earnings for females. Women who were admitted to a 2-year TVET program earned approximately 65,000 MNT per month more in their most recent job and on average as compared to those who were not admitted. The difference in total earnings at the point of the tracking survey is over 550,000 MNT and highly significant. These impacts are remarkably consistent in percentage terms, ranging from $25 \%$ to $26 \%$ across all four outcomes. As before, the estimates for men are not significant and close to zero.

To summarize, we find strong evidence that admission to TVET schooling increases earnings for women in 2-year programs, and these impacts appear to increase over time. There is no evidence that admission to a TVET school improved earnings for men.

\subsection{Intermediate outcomes}

We investigated a number of intermediate outcomes to better understand the mechanisms underlying the impacts on employment and earnings. All of the outcomes were reported in the 
GFU survey in the year after expected graduation and, for simplicity, these analyses are restricted to individuals who applied to 2-year programs (estimates are similar when including applicants to 1-year programs).

We begin by examining four outcomes related to the trades that individuals studied in TVET schools: (1) their standardized scores on a test of trade-related knowledge in their topranked trade, (2) their standardized scores on a test of trade-related knowledge in their 2nd-ranked trade, (3) whether individuals were currently employed in a paid job of longer than 1 month related to their TVET trade, and (4) whether individuals were ever employed in a paid job of longer than 1 month related to their TVET trade. The impacts of admission to a TVET school on these outcomes are presented in Table 12 below:

Table 12. Impact of admission to a TVET school on trade-related outcomes (2-year programs)

\begin{tabular}{|c|c|c|c|c|c|}
\hline Samples & $\begin{array}{c}(1) \\
\text { Test of knowledge } \\
\left(1^{\text {st }} \text { ranked trade }\right)^{\mathbf{i}}\end{array}$ & $\begin{array}{c}(2) \\
\text { Test of knowledge } \\
\left(2^{\text {nd }} \text { ranked }\right. \\
\text { trade })^{\mathbf{i}}\end{array}$ & $\begin{array}{c}\text { Currently } \\
\text { Cude } \\
\text { employed in trade }\end{array}$ & $\begin{array}{l}\text { Ever employed } \\
\text { in trade }\end{array}$ & (5) \\
\hline All & $\begin{array}{l}0.207 * * * \\
(0.0311)\end{array}$ & $\begin{array}{c}0.000998 \\
(0.0320)\end{array}$ & $\begin{array}{c}0.00920 \\
(0.00715)\end{array}$ & $\begin{array}{c}0.0324^{* * *} \\
(0.0121)\end{array}$ & \multirow[t]{2}{*}{$\begin{array}{l}\text { Up to } \\
9,878\end{array}$} \\
\hline Percentage impact & - & - & $15.5 \%$ & $15.3 \%$ & \\
\hline Male & $\begin{array}{c}0.230 * * * \\
(0.0406)\end{array}$ & $\begin{array}{c}-0.0341 \\
(0.0404)\end{array}$ & $\begin{array}{c}0.00162 \\
(0.00921)\end{array}$ & $\begin{array}{c}0.0182 \\
(0.0166)\end{array}$ & \multirow[t]{2}{*}{$\begin{array}{l}\text { Up to } \\
5,995\end{array}$} \\
\hline Percentage impact & - & - & $2.7 \%$ & $7.8 \%$ & \\
\hline Female & $\begin{array}{c}0.184 * * * \\
(0.0485)\end{array}$ & $\begin{array}{c}0.0651 \\
(0.0522)\end{array}$ & $\begin{array}{l}0.0195^{*} \\
(0.0112)\end{array}$ & $\begin{array}{c}0.0531 * * * \\
(0.0177)\end{array}$ & \multirow[t]{2}{*}{$\begin{array}{l}\text { Up to } \\
3,883\end{array}$} \\
\hline Percentage impact & - & - & $33.5 \%$ & $29.1 \%$ & \\
\hline
\end{tabular}

$\overline{\mathbf{i}}$ Tests of knowledge in the $1^{\text {st }}$ and $2^{\text {nd }}$ ranked trades are standardized to mean 0 , standard deviation 1

We see clear evidence that males and females who gained admission to a TVET school showed increased knowledge in their $1^{\text {st }}$ ranked trade, with impacts of approximately 0.2 standard deviation units. The absence of impacts for knowledge in the $2^{\text {nd }}$ ranked trade are not surprising given that so few students ended up studying them. On the other hand, only females were significantly more 
likely to be employed in fields related to the trade they studied in a TVET school. While the impacts are not significant for current employment, the percentage impacts are similar in magnitude to those associated with being ever employed.

We also examine several factors related to employment and work intensity: (1) whether individuals applied for or were offered job, (2) total months employed in paid jobs of longer than one month, (3) average number of days worked per month, and (4) average number of hours worked per day. The impacts of admission to a TVET school on these outcomes are presented below in Table 13:

Table 13. Impact of admission to a TVET school on work intensity (2-year programs)

\begin{tabular}{|c|c|c|c|c|c|}
\hline Samples & $\begin{array}{c}\text { (1) } \\
\text { Applied for or } \\
\text { was offered a job }\end{array}$ & $\begin{array}{c}\text { (2) } \\
\text { Total months } \\
\text { employed ( }>\text { 1 month) }\end{array}$ & $\begin{array}{l}\text { (3) } \\
\text { Average days / } \\
\text { month worked }\end{array}$ & $\begin{array}{c}(4) \\
\text { Average } \\
\text { hours / day } \\
\text { worked }\end{array}$ & $\begin{array}{l}\text { (5) } \\
\mathrm{N}\end{array}$ \\
\hline All & $\begin{array}{c}0.0579 * * * \\
(0.0133)\end{array}$ & $\begin{array}{c}0.110 \\
(0.134)\end{array}$ & $\begin{array}{c}1.258^{* * *} \\
(0.378)\end{array}$ & $\begin{array}{c}0.392 * * * \\
(0.148)\end{array}$ & 9,878 \\
\hline Percentage impact & $8.6 \%$ & $3.4 \%$ & $8.9 \%$ & $7.3 \%$ & \\
\hline Male & $\begin{array}{c}0.0614^{* * *} \\
(0.0169)\end{array}$ & $\begin{array}{c}0.179 \\
(0.191)\end{array}$ & $\begin{array}{l}0.922 * \\
(0.494)\end{array}$ & $\begin{array}{c}0.146 \\
(0.194)\end{array}$ & 5,995 \\
\hline Percentage impact & $8.5 \%$ & $4.6 \%$ & $5.7 \%$ & $2.4 \%$ & \\
\hline Female & $\begin{array}{l}0.0546 * * \\
(0.0215)\end{array}$ & $\begin{array}{l}0.0116 \\
(0.175)\end{array}$ & $\begin{array}{c}1.721^{* * *} \\
(0.582)\end{array}$ & $\begin{array}{c}0.732^{* * *} \\
(0.227)\end{array}$ & 3,883 \\
\hline Percentage impact & $8.9 \%$ & $0.5 \%$ & $15.0 \%$ & $16.9 \%$ & \\
\hline
\end{tabular}

Males and females who were admitted to a 2-year TVET program were significantly more likely to apply for a job or receive a job offer, with similar percentage impacts. Furthermore, females also worked significantly more days per month and hours per day relative to their counterparts who were not admitted to these TVET programs. While the impacts for men are positive and marginally significant for number of days worked, they are substantially smaller in magnitude and percentage impacts. These patterns may partially explain why only women saw higher earnings as a consequence of admission to TVET schools. 
Finally, we examine the type and sector of employment in more detail by considering the following outcomes: (1) whether individuals are employed in internships, (2) whether individuals are self-employed, (3) whether individuals are employed in the government sector, and (4) whether individuals are employed in the private sector. ${ }^{21}$ The impacts of admission to a TVET school on these outcomes are presented in the table below:

Table 12. Impact of admission to a TVET school on employment type/sector (2-year programs)

\begin{tabular}{|c|c|c|c|c|c|}
\hline Samples & $\begin{array}{c}(1) \\
\text { Employment } \\
\text { type: Internship }\end{array}$ & $\begin{array}{c}(2) \\
\text { Employment } \\
\text { type: Self- } \\
\text { employed }\end{array}$ & $\begin{array}{c}\text { Employed in } \\
\text { Government sector }\end{array}$ & $\begin{array}{c}\text { Employed in } \\
\text { private sector }\end{array}$ & $\begin{array}{l}\text { (5) } \\
\mathrm{N}\end{array}$ \\
\hline All & $\begin{array}{c}0.0279 * * \\
(0.0111)\end{array}$ & $\begin{array}{l}0.0126 * * \\
(0.00532)\end{array}$ & $\begin{array}{l}0.00974 * \\
(0.00539)\end{array}$ & $\begin{array}{l}0.0236^{*} \\
(0.0140)\end{array}$ & 9,878 \\
\hline Percentage impact & $16.8 \%$ & $34.6 \%$ & $31.1 \%$ & $4.9 \%$ & \\
\hline Male & $\begin{array}{c}0.0376^{* *} \\
(0.0154)\end{array}$ & $\begin{array}{c}0.0110 \\
(0.00715)\end{array}$ & $\begin{array}{c}0.00668 \\
(0.00770)\end{array}$ & $\begin{array}{l}0.00899 \\
(0.0186)\end{array}$ & 5,995 \\
\hline Percentage impact & $21.0 \%$ & $27.2 \%$ & $17.9 \%$ & $1.7 \%$ & \\
\hline Female & $\begin{array}{c}0.0151 \\
(0.0157)\end{array}$ & $\begin{array}{c}0.0146 * \\
(0.00806)\end{array}$ & $\begin{array}{c}0.0136^{*} \\
(0.00711)\end{array}$ & $\begin{array}{c}0.0438^{* *} \\
(0.0214)\end{array}$ & 3,883 \\
\hline Percentage impact & $10.3 \%$ & $47.3 \%$ & $59.0 \%$ & $11.0 \%$ & \\
\hline
\end{tabular}

While male applicants are much more likely to have an internship, female applicants are more likely to be employed in the government sector, the private sector, or to be self-employed. Because internships are unlikely to pay as well as government and private sector jobs, these differences by gender may further explain why men did not experience the same earnings gains as women.

\section{Conclusion}

This paper presents novel estimates for the effect of admission to formal vocational secondary programs on labor market outcomes, based on a recent intervention in Mongolia. We

\footnotetext{
${ }^{21}$ There are additional employment types and employment sectors (e.g. military, non-profits) but these represent a very small fraction of overall employment.
} 
used public lotteries to determine whether applicants to 10 oversubscribed vocational schools were accepted to their preferred trades in 2010,2011, and 2012, and then followed up on these applicants through 2015. We found that admission to oversubscribed vocational schools led to significantly higher employment, especially for women. We also found that women who were admitted to oversubscribed vocational schools had significantly higher earnings as compared to their counterparts who were not admitted. These findings are largely consistent with the impact on intermediate outcomes; we observe that admission to oversubscribed vocational schools led to improved skills in specific trades for both men and women, and to greater work intensity and increased employment opportunities in high-paying sectors for women.

There is also some evidence suggesting that the impact of vocational training in Mongolia depends on labor market conditions. When we observe positive impacts on labor market outcomes, the impacts are substantially higher for earlier cohorts and disappear for the latest cohort which entered the labor market during an economic downturn, especially for the mining industry. This pattern speaks to the possibility that the vocational training may be less transferable to other occupations in times of deteriorating labor market conditions. As noted by Goldin (2001) in reference to the past American experience, "highly specific training [is]...more cost effective for individuals who expect[ed] to spend their lives in the same place and in the same industry and occupation".

There are several directions for further research using this data. First, it would be interesting to examine the impact of admission to specific vocational trades. This may help shed light both on the heterogenous impacts for males vs. females (given the different composition of trades by gender) and on the different impacts by cohort (given that certain trades may have been more severely affected by the economic downturn). Second, it would be informative to examine 
the impact of admission to specific vocational schools, especially by the quality or selectivity of these schools. This could be helpful for understanding whether the source of the positive impacts is due to the vocational training per se, or simply the higher quality of the schools. Finally, it would be extremely useful to conduct a further follow-up on these students to examine whether the short and medium-term impact persist over time. 


\section{References}

Abdulkadiroglu, Atila, Joshua Angrist, Yusuke Narita, Parag Pathak. 2015. Research Design Meets Market Design: Using Centralized Assignment for Impact Evaluation. NBER Working Paper No. 21705.

Attanasio, Orazio, Adriana Kugler, and Costas Meghir. 2011. "Subsidizing Vocational Training for Disadvantaged Youth in Colombia: Evidence from a Randomized Trial." American Economic Journal: Applied Economics. 3(3): 188-220.

Attanasio, Orazio, Arlen Guarín, Carlos Medina, Costas Meghir. 2015. "Long Term Impacts of Vouchers for Vocational Training: Experimental Evidence for Colombia" NBER Working Paper No. 21390.

Bandiera, Oriana, Robin Burgess, Narayan Das, Selim Gulesci, Imran Rasul, Munshi Sulaiman 2013. "Can basic entrepreneurship transform the economic lives of the poor?" Mimeo.

Bandiera, O., Buehren, N., Burgess, R., Goldstein, M., Gulesci, S., Rasul, I. and Sulaiman, M. 2014. "Empowering adolescent girls: evidence from a randomized control trial in Uganda" Mimeo.

Bennel, P., 1996. "General versus Vocational Secondary Education in Developing Countries: A Review of the Rates of Return Evidence," Journal of Development Studies 33 (2): 230-247

Bettinger, Eric, Michael Kremer and Juan Saavedra 2010. “Are Education Vouchers Only Redistributive?" Economic Journal 120(546), 204-228

Blattman, C., Fiala, N. and Martinez, S. 2014. "Generating skilled self-employment in developing countries: experimental evidence from Uganda", Quarterly Journal of Economics, vol. 129(2), pp. 697-752.

Card, D., Ibarraran, P., Regalia, F., Rosas-Shady, D. and Soares, Y. 2011. "The labor market impacts of youth training in the Dominican Republic", Journal of Labor Economics, 29(2): 267300 .

Cho, Yoonyoung, Davie Kalomba, A. Mushfiq Mobarak, and Victor Orozco. 2013. "Gender Differences in the Effects of Vocational Training: Constraints on Women and Dropout Behavior.” IZA Discussion Paper 7408.

Cullen, Julie Berry, Brian A. Jacob, and Steven D. Levitt, 2005. The impact of school choice on student outcomes: an analysis of the Chicago Public Schools, Journal of Public Economics 89(56):729-60.

Hicks, Joan, Michael Kremer, Isaac Mbiti, and Edward Miguel. 2013. "Vocational Education in Kenya: Evidence from a Randomized Evaluation among Youth.” Mimeo. 
Hirshleifer, S., McKenzie, D., Almeida, R. and Ridao-Cano, C. 2016. "The impact of vocational training for the unemployed: Experimental evidence from Turkey", The Economic Journal. 126: 2115-2146.

IBRD, 1995. World Bank Policy Paper: Vocational and Technical Education and Training. Washington DC: World Bank.

Innovations for Poverty Action (IPA), 2013. Baseline Report for the TVET admissions survey (2010-2012). Available at: https://data.mcc.gov/evaluations/index.php/catalog/82

Innovations for Poverty Action (IPA), 2018. Final Evaluation Report: Measuring Results of the Mongolia I Compact Vocational Education (VET) Project. Available at: https://data.mcc.gov/evaluations/index.php/catalog/82

Kahn, L.B. 2010. "The long-term labor market consequences of graduating from college in a bad economy" Labour Economics, 17(2): 303-316

Kemple, James J. and Jason Snipes. 2000. Career Academies: Impacts on Student Engagement and Performance in High School. Manpower Demonstration Research Corporation report.

Malamud, Ofer and Cristian Pop-Eleches (2010) "General Education vs. Vocational Training: Evidence from an Economy in Transition," Review of Economics and Statistics 92(1): 43-60

Maitra, Pushkar and Subha Mani. 2012. 'Learning and earning: evidence from a randomized evaluation in India', mimeo, Department of Economics, Monash University.

Millennium Challenge Corporation (MCC). 2007. Millenium Challenge Compact between the United States of America acting through the Millennium Challenge Corporation and the Government of Mongolia. Available at: https://assets.mcc.gov/agreements/compactmongolia.pdf

Millennium Challenge Corporation (MCC). 2009. Report on Modification to the Millennium Challenge Compact between the United States of America, acting through the Millennium Challenge Corporation, and the Government of Mongolia. Available at: https://assets.mcc.gov/cn/cn-121109-mongolia-amendment.pdf

Millennium Challenge Corporation (MCC). 2013. Post-Compact Monitoring \& Evaluation Plan Mongolia. Available at: https://assets.mcc.gov/content/uploads/2017/05/ME_Plan__MNG_V5 - Post-Compact.pdf

Millennium Challenge Corporation (MCC). 2014. Mongolia Compact. Available at: https://www.mcc.gov/where-we-work/program/mongolia-compact

Mongolian Ministry of Economic Development. 2013. Millennium Development Goals Fifth National Progress Report 2013. Available at: http://www.mn.undp.org/content/dam/mongolia/Publications/MDGreports/MDG5 ReportSumm ary Eng.pdf 
Oreopoulos, P., T. von Wachter, and A. Heisz. 2012. "The Short- and Long-Term Career Effects of Graduating in a Recession." American Economic Journal: Applied Economics, 4 (1): 1-29.

Oyer, P. 2006. "Initial Labor Market Conditions and Long-Term Outcomes for Economists." Journal of Economic Perspectives, 20 (3): 143-160

Psacharapoulos, G. 1987. "To Vocationalize or Not to Vocationalize?: That is the Curriculum Question”. International Review of Education 33(2): 583-97.

Psacharapoulos, G. 1993. Returns to Investment in Education: A Global Update. WPS. Washington DC: World Bank.

Tilak, J. 1988. "Economics of Vocationalization: A Review of the Evidence" Canadian and International Education 17(1). 


\section{Appendix Tables}

Appendix Table 1. Balance of baseline characteristics between those admitted to TVET through the lottery and those not admitted

\begin{tabular}{|c|c|c|}
\hline Baseline characteristics & $\begin{array}{l}\text { Mean: Control } \\
\text { Group }^{1}\end{array}$ & $\begin{array}{c}\text { Difference: } \\
\text { Treatment-Control }{ }^{2} \\
\text { <std. error }>\end{array}$ \\
\hline Age & 16.15 & $\begin{array}{l}-0.00 \\
(0.03)\end{array}$ \\
\hline Male (\%) & 0.57 & $\begin{array}{c}0.00 \\
(0.01)\end{array}$ \\
\hline Has Prior Work Experience (\%) & 0.04 & $\begin{array}{l}-0.00 \\
(0.01)\end{array}$ \\
\hline Applicant Years of Schooling & 9.04 & $\begin{array}{l}-0.01 \\
(0.01)\end{array}$ \\
\hline Applicant GPA (Out of 100) & 74.13 & $\begin{array}{c}0.08 \\
(0.19)\end{array}$ \\
\hline Percent Correct on Entrance Exam (Math section) & 0.38 & $\begin{array}{l}-0.01 \\
(0.01)\end{array}$ \\
\hline Percent Correct on Entrance Exam (Logic and Problem Solving section) & 0.31 & $\begin{array}{l}-0.00 \\
(0.01)\end{array}$ \\
\hline Percent Correct on Entrance Exam (Reading section) & 0.32 & $\begin{array}{l}-0.00 \\
(0.01)\end{array}$ \\
\hline Percent Correct on Entrance Exam (Essay section) & 0.40 & $\begin{array}{l}-0.00 \\
(0.01)\end{array}$ \\
\hline Percent Correct on Entrance Exam (Overall) & 0.35 & $\begin{array}{l}-0.00 \\
(0.00)\end{array}$ \\
\hline Head of Household is Applicant's Father (\%) & 0.76 & $\begin{array}{l}-0.02 \\
(0.01)\end{array}$ \\
\hline Household Head Years of Schooling & 8.86 & $\begin{array}{l}0.06 \\
(0.06)\end{array}$ \\
\hline Household Head is Employed (\%) & 0.57 & $\begin{array}{l}-0.02 \\
(0.01)\end{array}$ \\
\hline Number of Household Members & 5.10 & $\begin{array}{c}-0.09 * * \\
(0.04)\end{array}$ \\
\hline Lives in Ger (\%) & 0.62 & $\begin{array}{l}-0.00 \\
(0.01)\end{array}$ \\
\hline Owns Home (\%) & 0.96 & $\begin{array}{c}0.00 \\
(0.01)\end{array}$ \\
\hline A Family Member Practices the First Choice Trade (\%) & 7.27 & $\begin{array}{c}0.47 \\
(0.77)\end{array}$ \\
\hline Monthly Family Income is Below 50,000 MNT (\%) & 0.05 & $\begin{array}{c}0.01 \\
(0.01)\end{array}$ \\
\hline Monthly Family Income is Between 50,000 and 100,000 MNT (\%) & 0.14 & $\begin{array}{c}0.00 \\
(0.01)\end{array}$ \\
\hline Monthly Family Income is Between 100,000 and 200,000 MNT (\%) & 0.26 & $\begin{array}{l}-0.00 \\
(0.01)\end{array}$ \\
\hline Monthly Family Income is Between 200,000 and 300,000 MNT (\%) & 0.21 & $\begin{array}{c}0.00 \\
(0.01)\end{array}$ \\
\hline Monthly Family Income is Between 300,000 and 500,000 MNT (\%) & 0.17 & $\begin{array}{c}0.01 \\
(0.01)\end{array}$ \\
\hline Monthly Family Income is Over 500,000 MNT (\%) & 0.12 & $\begin{array}{c}-0.02^{* *} \\
(0.01)\end{array}$ \\
\hline Expected Monthly Income While in School (1000's of MNT) & 44.70 & $\begin{array}{l}-0.01 \\
(0.40)\end{array}$ \\
\hline $\begin{array}{l}\text { Expected Monthly Income After Graduation if Admitted to First Choice Trade } \\
\text { (1000's of MNT) }\end{array}$ & 347.98 & $\begin{array}{l}-4.25 \\
(4.56)\end{array}$ \\
\hline
\end{tabular}


Expected Time Spent Searching for a Job After Graduation if Admitted to First Choice Trade (Months)

\begin{tabular}{|c|c|}
\hline 2.34 & $\begin{array}{l}-0.05 \\
(0.07)\end{array}$ \\
\hline \multirow[t]{2}{*}{0.80} & 0.01 \\
\hline & $(0.01)$ \\
\hline \multirow[t]{2}{*}{145.74} & 4.42 \\
\hline & $(5.22)$ \\
\hline \multirow[t]{2}{*}{1.77} & 0.01 \\
\hline & (0.09) \\
\hline \multirow[t]{2}{*}{0.39} & -0.01 \\
\hline & $(0.01)$ \\
\hline \multirow{2}{*}{1.98} & 0.12 \\
\hline & $(0.17)$ \\
\hline \multirow[t]{2}{*}{11.35} & 0.78 \\
\hline & (1.07) \\
\hline \multirow[t]{2}{*}{1.34} & 0.11 \\
\hline & $(0.14)$ \\
\hline \multirow[t]{2}{*}{9.81} & -0.12 \\
\hline & (1.07) \\
\hline \multirow[t]{2}{*}{0.25} & -0.03 \\
\hline & $(0.04)$ \\
\hline \multirow[t]{2}{*}{30.26} & $-2.50 *$ \\
\hline & (1.29) \\
\hline \multirow[t]{2}{*}{24.64} & -1.43 \\
\hline & (1.10) \\
\hline \multirow[t]{2}{*}{53.24} & 1.24 \\
\hline & (1.34) \\
\hline \multirow[t]{2}{*}{32.64} & -0.43 \\
\hline & (1.29) \\
\hline \multirow[t]{2}{*}{61.61} & -0.81 \\
\hline & (1.31) \\
\hline \multirow[t]{2}{*}{29.78} & -0.75 \\
\hline & (1.31) \\
\hline \multirow[t]{2}{*}{95.10} & $-1.60 * *$ \\
\hline & $(0.71)$ \\
\hline \multirow[t]{2}{*}{33.59} & 0.58 \\
\hline & $(1.26)$ \\
\hline
\end{tabular}

Will Attend Another School if Not Admitted (\%)

Expected Monthly Income After Graduation if Not Admitted (1000's of MNT)

Expected Time Spent Searching for a Job if Not Admitted (Months)

A Household Member Owns Livestock (\%)

Number of Cows Owned

Number of Goats Owned (2)

Number of Horses Owned

Number of Sheep Owned

Number of Camels Owned

Owns an Automobile (\%)

Owns a Computer (\%)

Owns a Clothes-Washing Machine (\%)

Owns a Motorcycle (\%)

Owns a Refrigerator (\%)

Owns a Satellite Dish (\%)

Owns a Television (\%)

Owns a Vacuum Cleaner (\%)

Standard errors in parentheses

$* * * \mathrm{p}<0.01, * * \mathrm{p}<0.05, * \mathrm{p}<0.1$

${ }^{1}$ The second column gives the average value for the sample of students not admitted to a TVET school through the lottery.

${ }^{2}$ The third column gives the coefficient on an indicator variable that is 1 if students were admitted to a TVET school through the lottery and 0 otherwise.

$\mathrm{N}=10,950$ students who were administered the Graduate Follow Up survey 
Appendix Table 2. Differential attrition between applicants accepted and not accepted to TVET school

\begin{tabular}{lcccc}
\hline & $(1)$ & $(2)$ & $(3)$ & $(4)$ \\
& $\begin{array}{c}\text { All } \\
\text { Accepted to } \\
\text { TVET }\end{array}$ & $\begin{array}{c}\mathbf{2 0 1 0} \\
\text { Accepted to } \\
\text { TVET }\end{array}$ & $\begin{array}{c}\mathbf{2 0 1 1} \\
\text { Accepted to } \\
\text { TVET }\end{array}$ & $\begin{array}{c}\mathbf{2 0 1 2} \\
\text { Accepted to } \\
\text { TVET }\end{array}$ \\
\hline $\begin{array}{l}\text { Interviewed as part of the graduate } \\
\text { follow up survey }\end{array}$ & $\begin{array}{c}0.0259^{* * *} \\
(0.00768)\end{array}$ & $0.0269 * *$ & $0.0387^{* *}$ & 0.00854 \\
& & $(0.0105)$ & $(0.0152)$ & $(0.0155)$ \\
\hline
\end{tabular}

$* * * \mathrm{p}<0.01, * * \mathrm{p}<0.05, * \mathrm{p}<0.1$

${ }^{1}$ The coefficients are estimated using the following model:

$G F U_{i j k l m}=\beta_{0}+\beta_{1}$ TVETaccepted $i+f\left(p_{i j k l m}\right)+\varepsilon$

Where $G F U_{i}$ is a binary outcome variable equal to 1 for student $i$ in school $k$ participating in round $l$ of the lottery for cohort $m$ who took the GFU survey and 0 otherwise. TVETaccepted $d_{i}$ is a binary variable equal to 1 for students accepted through the lottery and 0 otherwise $f\left(p_{i j k l m}\right)$ is a polynomial of the probability that each student was assigned to an improved trade given their and their peers' trade preferences.

The coefficients on TVETaccepted ${ }_{i}$ estimate differences in the attrition of applicants who were admitted and those not-admitted.

Appendix Table 3. Attrition analysis: Differences between admitted vs. non-admitted among those not-interviewed

\begin{tabular}{lcc}
\hline Baseline characteristics & $\begin{array}{c}\text { Accepted to } \\
\text { TVET coefficient }^{1}\end{array}$ & $\begin{array}{c}\text { Standard } \\
\text { error }^{-}\end{array}$ \\
\hline Age & $0.160^{*}$ & $(0.0847)$ \\
Male (\%) & 2.589 & $(3.406)$ \\
Has Prior Work Experience (\%) & -0.304 & $(1.552)$ \\
Applicant Years of Schooling & -0.00159 & $(0.0243)$ \\
Applicant GPA (Out of 100) & -0.588 & $(0.465)$ \\
Percent Correct on Entrance Exam (Math section) & -2.321 & $(1.523)$ \\
Percent Correct on Entrance Exam (Logic and Problem Solving section) & 1.118 & $(1.325)$ \\
Percent Correct on Entrance Exam (Reading section) & 0.0420 & $(1.825)$ \\
Percent Correct on Entrance Exam (Essay section) & 0.644 & $(1.831)$ \\
Percent Correct on Entrance Exam (Overall) & -0.226 & $(1.008)$ \\
Head of Household is Applicant's Father (\%) & -2.764 & $(3.069)$ \\
Household Head Years of Schooling & -0.0379 & $(0.164)$ \\
Household Head is Employed (\%) & -3.374 & $(3.355)$ \\
Number of Household Members & -0.173 & $(0.112)$ \\
Lives in Ger (\%) & -2.093 & $(3.061)$ \\
Owns Home (\%) & -0.937 & $(1.265)$ \\
A Family Member Practices the First Choice Trade (\%) & 0.499 & $(1.937)$ \\
Monthly Family Income is Below 50,000 MNT (\%) & 1.946 & $(1.647)$ \\
Monthly Family Income is Between 50,000 and 100,000 MNT (\%) & -0.157 & $(2.522)$ \\
Monthly Family Income is Between 100,000 and 200,000 MNT (\%) & 0.644 & $(3.166)$ \\
Monthly Family Income is Between 200,000 and 300,000 MNT (\%) & 1.621 & $(2.931)$ \\
Monthly Family Income is Between 300,000 and 500,000 MNT (\%) & -1.102 & $(2.554)$ \\
Monthly Family Income is Over 500,000 MNT (\%) & -1.146 & $(2.005)$ \\
Expected Monthly Income While in School (1000's of MNT) & -0.885 & $(0.997)$
\end{tabular}


Expected Monthly Income After Graduation if Admitted to First Choice Trade (1000's of MNT)

Expected Time Spent Searching for a Job After Graduation if Admitted to First Choice Trade (Months)

$-0.00865$

$5.319 *$

$25.14^{* *}$

0.255

0.722

0.105

4.268

0.799

2.225

$-0.331$

3.682

0.882

1.829

2.644

$-2.226$

$-3.706$

$-0.388$

$-0.633$

\section{*** $\mathrm{p}<0.01, * * \mathrm{p}<0.05, * \mathrm{p}<0.1$}

${ }^{1}$ The coefficients are estimated using the following model:

$Y_{i j k l m}=\beta_{0}+\beta_{1}$ TVETaccepted $_{i}+\beta_{2}$ GFU $_{i}+\beta_{3}$ TVETaccepted $_{i} *$ GFU $_{i}+f\left(p_{i j k l m}\right)+\varepsilon$

Where $Y_{i j k l m}$ is the baseline outcome for student $i$ in school $k$ participating in round $l$ of the lottery for cohort $m$. TVETaccepted $d_{i}$ is a binary variable equal to 1 for students accepted through the lottery and 0 otherwise. $G F U_{i}$ is a binary variable equal to 1 for students who took the GFU survey and 0 otherwise. TVETaccepted TV $G F U_{i}$ is an interaction between the two binary variables. $f\left(p_{i j k l m}\right)$ is a polynomial of the probability that each student was assigned to an improved trade given their and their peers' trade preferences.

The coefficients on TVETaccepted ${ }_{i}$ estimate differences between respondents accepted to TVET through the lottery but not interviewed for the graduate follow up survey, and those not accepted to TVET through the lottery and not interviewed. 
Appendix Table 4. Compliance by school among all 10,950 Graduate Follow Up respondents

\begin{tabular}{lccccc}
\hline Samples & $\begin{array}{c}\text { Graduated from } \\
\text { assigned TVET school }\end{array}$ & $\begin{array}{c}\text { Enrolled in TVET } \\
\text { assigned school }\end{array}$ & $\begin{array}{c}(1) \\
\text { Enrolled in } \\
\text { evaluation school }\end{array}$ & $\begin{array}{c}(4) \\
\text { Graduated from } \\
\text { evaluation school }\end{array}$ & $\mathrm{N}$ \\
\hline year & $0.229^{* * *}$ & $0.110^{*}$ & $0.116^{*}$ & 0.0679 & 1,072 \\
Students & $(0.0387)$ & $(0.0631)$ & $(0.0629)$ & $(0.0618)$ & \\
2 year & $0.504^{* * *}$ & $0.312^{* * *}$ & $0.266^{* * *}$ & $0.268^{* * *}$ & 9,878 \\
Students & $(0.00911)$ & $(0.0137)$ & $(0.0139)$ & $(0.0139)$ & \\
\hline
\end{tabular}

Standard errors in parentheses

$* * * p<0.01, * * p<0.05, * p<0.1$

Appendix Table 5. Compliance by trade among all 10,950 Graduate Follow Up respondents

\begin{tabular}{|c|c|c|c|c|c|}
\hline Samples & $\begin{array}{c}\text { (1) } \\
\text { Studied first } \\
\text { ranked trade }\end{array}$ & $\begin{array}{c}\text { (2) } \\
\text { Studied second } \\
\text { ranked trade }\end{array}$ & $\begin{array}{c}(3) \\
\text { Graduated from } \\
\text { first ranked trade }\end{array}$ & $\begin{array}{c}\text { (4) } \\
\text { Graduated from } \\
\text { second ranked trade }\end{array}$ & $\begin{array}{l}\text { (5) } \\
\mathbf{N}\end{array}$ \\
\hline 1 year students & $\begin{array}{c}0.148 * * * \\
(0.0449)\end{array}$ & $\begin{array}{c}0.0541 * * \\
(0.0213)\end{array}$ & $\begin{array}{c}0.129 * * * \\
(0.0446)\end{array}$ & $\begin{array}{c}0.0417^{* *} \\
(0.0184)\end{array}$ & 1,072 \\
\hline 2 year students & $\begin{array}{c}0.270 * * * \\
(0.0125)\end{array}$ & $\begin{array}{c}0.0321 * * * \\
(0.00735)\end{array}$ & $\begin{array}{c}0.251 * * * \\
(0.0121)\end{array}$ & $\begin{array}{c}0.0334^{* * *} \\
(0.00678)\end{array}$ & 9,878 \\
\hline
\end{tabular}

Standard errors in parentheses

$* * * p<0.01, * * p<0.05, * p<0.1$ 